\title{
ECONOMICS
}

\section{THE DEEP HISTORICAL ROOTS OF MACROECONOMIC VOLATILITY}

\author{
by \\ Sam Hak Kan Tang \\ Business School \\ University of Western Australia \\ and
}

Charles Ka Yui Leung

Department of Economics and Finance City University of Hong Kong 


\title{
THE DEEP HISTORICAL ROOTS OF MACROECONOMIC VOLATILITY
}

\author{
Sam Hak Kan Tang ${ }^{\mathrm{a}}$ \\ and \\ Charles Ka Yui Leung ${ }^{\mathrm{b}}$
}

DISCUSSION PAPER 14.31

\begin{abstract}
We present cross-country evidence that a country's macroeconomic volatility, measured either by the standard deviation of output growth or the occurrence of trend-growth breaks, is significantly affected by the country's historical variables. In particular, countries with longer histories of state-level political institutions experience less macroeconomic volatility in postwar periods. In addition, we show that political instability, discretionary fiscal policy, financial underdevelopment, and a lack of foreign direct investment are the main mechanisms by which state history affects the macroeconomic volatility of modern states.

JEL classification: O10, O33, O43

Keywords: Macroeconomic volatility, State history, History of agriculture, Technology adoption, Political stability, Discretionary fiscal policy, Financial development, FDI inflow.

a. Business School, the University of Western Australia, 35 Stirling Highway, Crawley WA 6009, Australia. Tel: +618-6488-2931. Fax: +618-6488-1016. E-mail: sam.tang@uwa.edu.au.

b. Department of Economics and Finance, the City University of Hong Kong, Kowloon Tong, Hong Kong. Email: kycleung@cityu.edu.hk.

* Acknowledgments. We are indebted to all of the researchers investigating historical variables who have generously made their datasets available to the public. We would like to thank Harry Bloch, who provided invaluable comments on an earlier draft of this paper. Constructive comments from participants at the brownbag Economics seminar series at the University of Western Australia are also acknowledged. We wish to thank the University of Western Australia and the City University of Hong Kong for their financial support. The work described in this paper was partially supported by a grant from the Research Grants Council of the Hong Kong Special Administrative Region, China [Project No. CityU 146112]. All remaining errors are our own.
\end{abstract}




\section{Introduction}

In the recent growth literature, the search for the fundamental factors of economic prosperity has traced its roots to variables of pre-historic times, dating back to more than 10,000 B.C.E. This line of research has produced empirical evidence that current cross-country income differences are related to several key historical variables: the biogeographic conditions that determined the timing of the Neolithic Revolution (Diamond, 1997; Hibbs and Olsson, 2004; Olsson and Hibbs, 2005), the history of state-level political institutions (Bockstette, Chanda and Putterman, 2002; Putterman and Weil, 2010), the history of agriculture (Putterman and Weil, 2010), the history of technology adoption (Comin, Easterly and Gong, 2010), genetic distance from the frontier (Spolaore and Wacziarg, 2009), and genetic diversity of the population (Ashraf and Galor, 2013). ${ }^{1}$ These seminal studies have not only provided stimulating insights, but have also made available rich datasets of historical variables that have stimulated further research in this direction. We draw on these datasets to address the following questions. Do historical variables affect macroeconomic volatility today? If so, which variables are most important? What are the mechanisms by which these historical variables influence current macroeconomic volatility?

Clearly, this research is inspired by a strand of studies in the literature which focuses on the fundamental factors of macroeconomic volatility, especially in developing countries. The results of these studies show that distortionary or discretionary policies that cause high macroeconomic volatility and economic crises are themselves the "symptoms" of weak institutional quality, unfavorable geography or less democratic political systems. Among others, Rodrik (1999) argues that divided societies and weak conflict management at the institutional level amplify external shocks, causing volatile growth and crises. Acemoglu,

\footnotetext{
${ }^{1}$ See Spolaore and Wacziarg (2013) for a summary of this growing body of literature. Nunn (2009) provides a survey of the literature on the importance of history to economic development.
} 
Johnson, Roberson and Thaicharoen (2003) (henceforth AJRT, 2003) show that countries that inherited more "extractive” institutions from their former European colonizers are more likely to experience high volatility and economic crises during post-war periods. Fatás and Mihov (2003) find that institutional environments that impose few constraints on governance via checks and balances experience greater discretion in fiscal policy, which causes macroeconomic instability. Malik and Temple (2009) provide evidence that remote countries with poor market access are more likely to have undiversified exports and to experience greater volatility in output growth. There is also substantial evidence that less democratic countries experience more macroeconomic volatility. For instance, Mobarak (2005) finds that countries with Muslim-majority populations are less democratic, which increases volatility. Our work is closely related to research on the fundamental factors shaping macroeconomic volatility. However, we look much more deeply into history to determine whether and how human evolution in the last 10,000 years continues to influence macroeconomic volatility today.

This paper makes two contributions to the literature. First, we show that countries with longer histories of state-level political institutions experience less macroeconomic volatility in post-war periods. ${ }^{2}$ The effect of this historical variable is manifested not only in high-frequency volatility, measured by the standard deviation of annual output growth, but in medium-term volatility, measured by the occurrence of trend-growth breaks. In addition, robustness checks reveal that the effect of this historical variable on volatility remains significant and substantial after controlling for a host of structural variables investigated in

\footnotetext{
${ }^{2}$ A country's history of state-level political institutions is measured by the extent to which the country was controlled by a government above tribal level from 1 to 1950 C.E. This historical variable is adjusted for the proportion of the territory of the modern country ruled by the government during this period, and also for whether its government was foreign or locally based. See Section 2 for a detailed description of this historical variable. See also Acemoglu et al. (2013) for a related analysis of "weak states."
} 
previous studies. Moreover, adding current income to the list of regressors does not eliminate the significant effect of this historical variable on volatility, suggesting that state history affects current macroeconomic volatility through independent channels, rather than through the growth channel alone. ${ }^{3}$

Our second contribution to the literature is the finding that the effects of state history are multidimensional, and principally affect output volatility through political and financial frameworks. A long history of state-level political institutions reduces the degree of political risk and enhances political constraints on fiscal-policy discretion. It also facilitates financial development and attracts foreign direct investment (FDI). The results of previous studies show that political stability (AJRT, 2003; Klomp and Haan, 2009), discretionary fiscal policy (Fatás and Mihov, 2003), financial development (Ferreira da Silva, 2002; Raddatz, 2006), and FDI inflow (Lensink and Morrissey, 2006) are important covariates of output volatility. We add to the literature by showing that the history of state-level political institutions has a significant effect on all of these important "proximate" factors of output volatility. We also show that once the effect of state history on these proximate factors is accounted for, there is little left in explaining output volatility, suggesting that these proximate factors are the main drivers through which state history affects macroeconomic volatility.

Why does the history of state-level political institutions have such a strong influence on macroeconomic volatility and its proximate factors today? Although it is beyond the scope of this paper to review the related literature, it may be instructive to highlight certain contributions. ${ }^{4}$ Diamond (1997) argues that people living in countries with long histories of

\footnotetext{
${ }^{3}$ The terms "state history" and "the history of state-level political institutions" are used interchangeably throughout the paper.

${ }^{4}$ See Engerman and Sokoloff (2012), among others, for a review of the institution literature.
} 
nationhood are more likely to have a sense of common identity and a common language. ${ }^{5}$ Sharing an identity and a language fosters trust and social interaction, which are important components of social capital (Temple, 1998). Knack and Keefer (1997) find that social capital, as measured by trust and civic norms, is higher in countries that are less polarized in terms of ethnicity and class. Putterman and Weil (2010) show that trust, control, respect, obedience and thriftiness are all positively affected by state history. In addition, a unified state with a common national identity and language is less likely to experience the devastating effects of civil war and other forms of political instability (Easterly and Levine, 1997). Bockstette, Chanda and Putterman (2002) argue that through learning by doing, public administration is more effective in long-standing states. Also, long-standing states may develop better bureaucratic discipline and hierarchical control. Hence, countries with longer histories of nationhood are likely to be more stable because they may have higher social capital, fewer civil wars and other forms of political instability, more effective administration, and greater bureaucratic discipline and hierarchical control.

The remainder of this paper is divided into four sections. Section 2 presents the definitions and constructions of the two measures of macroeconomic volatility and the historical variables used in the regressions. Section 3 presents empirical evidence for linking historical variables to macroeconomic volatility. In particular, we show in Section 3 that the history of state-level political institutions has an important role in explaining macroeconomic volatility today, especially in more volatile countries. ${ }^{6}$ Section 4 investigates the channels

\footnotetext{
${ }^{5}$ A common language also reinforces national identity. Clots-Figueras and Masella (2013) show that teaching Catalan in Catalonian schools instils greater loyalty to the Catalan identity, and affects political preferences and attitudes toward the organization of the state.

${ }^{6}$ To save space, we present and discuss the results of further robustness checks of the baseline estimates in Appendix B. These results show that the baseline estimates are unaffected by adding more structural variables that are well known to be related to macroeconomic volatility.
} 
through which state history may affect output volatility, and provides evidence that political stability, discretionary fiscal policy, financial development and FDI inflow channel the effects of state history on output volatility. In Section 4, we also present the results of twostage least squares (2SLS) and limited information maximum likelihood (LIML) instrumental variable estimators, which confirm that the above-mentioned channels are both causal and insensitive to further robustness checks. In the last section, we summarize our findings and conclude the paper.

\section{Data Description}

This section describes the main variables used in this study, with particular attention given to two measures of macroeconomic volatility and four historical variables. A detailed description of the other variables used in the regressions is provided in Appendix A.

\subsection{Macroeconomic Volatility-Output Volatility and Occurrence of Trend-Growth Breaks}

The vast majority of researchers examining macroeconomic volatility use the standard deviation of output growth as a measure of macroeconomic volatility (Klomp and Haan, 2009). Output volatility is measured by calculating the standard deviation of the annual growth rates of real gross domestic product (GDP) per capita between 1960 and 2011. The annual growth rates of real GDP are log differences of annual GDP per capita in constant local currency. The standard deviation of annual output growth captures the total variation in output growth due to business-cycle fluctuations, crises, and changes in trends; not just the variation arising from uncertainty or unpredictability. It is worth noting that output variation incurs some costs even when the variation is fully anticipated, especially when individuals have limited opportunities for consumption smoothing. 
Although the standard deviation of output growth captures (relatively) high-frequency shocks, some researchers argue that this measure is not ideal when a country's economic growth is characterized by frequent episodes of accelerated growth and growth breaks, which is the case for many developing countries. For instance, Pritchett (2000) describes the different patterns of growth of developing countries as hills among plateaus, mountains, and plains. Jones and Olken (2005) find that most countries experience growth miracles and failures over substantial periods, and that productivity plays a significant role in accounting for patterns of start-stop growth. Hence, we also consider the relationship between historical variables and medium-run trend-growth volatility measured by the occurrence of trendgrowth breaks, which is a dummy variable that takes the value of 1 if a country experiences at least one structural break (trend-growth break) during the sample period, and 0 otherwise. The data on structural breaks are taken from Jones and Olken (2005), who use a method developed by Bai and Perron (1998, 2003) to identify 73 structural breaks in 48 of 125 countries with at least 20 years of Penn World Table data.

\subsection{History of State-Level Political Institutions}

The history of state-level political institutions is the "State Antiquity Index Version 3.1" obtained from Putterman (2004), which measures the existence of any form of central state from 1 to 1950 C.E. in the history of a modern country. The index adjusts for the scope of a state's geographical control between 1 and 1950 C.E., and whether the state was indigenous or controlled by an outside power during that period. The index is constructed using the following formula:

$$
\text { statehist }=\frac{\sum_{t=0}^{39}(1.05)^{-t} s_{i, t}}{\sum_{t=0}^{39} 50 *(1.05)^{-t}}
$$

where $s_{i t}$ is the state-history variable for country $i$ in the 50 -year period $t$. For each of the 39 50-year periods, a country receives 1 point if it has a government above the tribal level (and 0 
points otherwise), 1 point if its government is locally based ( 0.5 points if the country is controlled by an outside power, and 0.75 points if local and foreign powers share its governance), and 1 point if the government controls more than 50 percent of the territory of the modern country ( 0.75 points if $25-50$ percent of the country's territory is under government control, 0.5 points if $10-25$ percent is under government control, and 0.3 points if less than 10 percent is under government control). The three scores are then multiplied by each other, and the result is multiplied by 50 to give $s_{i t}$. Take, for example, a country with a foreign government above the tribal level that ruled 30 percent of the territory of the modern country. This country has an $s_{i t}$ value of $18.75(1 \times 0.5 \times 0.75 \times 50)$ for the 50 -year period $t$.

As older data are less reliable, $s_{i t}$ is thus discounted by additional 5 percent for each 50-year period before 1901-1950 C.E. For example, an $s_{i t}$ value of 18.75 for the 50-year period from 1801 to 1850 is discounted by $(1.05)^{-2}$ to give 17.01 . Finally, dividing the discounted sum of the state-history variables, $s_{i t}$, by the maximum achievable value gives the state-history index, which varies between 0 and 1.

The state-history index measures a country's history of state-level political institutions between 1 and 1950 C.E. However, some countries have experienced massive population migration since 1500 C.E. as a result of European colonization. Consequently, to measure the state history of the ancestors of the current population of a country, as opposed to the state history of the country, we use the World Migration Matrix (WMM) to adjust the state-history index for population migration since 1500 C.E. ${ }^{7}$ The adjustment is made because the history of a country's current population has a greater effect than the history of the country on the

\footnotetext{
${ }^{7}$ More specifically, we multiply the state-history index by the WMM, which is constructed by Putterman and Weil (2010). The WMM gives the share of the population in every country in 2000 C.E. descended from people in different source countries in 1500 C.E.
} 
country’s economic outcomes. Most countries have experienced little population migration, and thus show little difference between the two variables. ${ }^{8}$

\subsection{History of Agriculture}

Drawing on a variety of sources, Putterman and Trainor (2006) assemble data on the transition from hunting and gathering to agriculture. The variable gives the number of years (in thousands) prior to 2000 since a significant number of people in an area within the country's present borders met most of their food needs by cultivating crops. Similar to the history of state-level political institutions, this variable is adjusted for population migration using the WMM.

\subsection{History of Technology Adoption}

We use technology-adoption indices constructed by Comin, Easterly and Gong (2010) to measure the level of technology adoption in the agricultural, transportation, communications, industry, and military sectors of a maximum of 135 countries in 1000 B.C.E, 1 C.E. and 1500 C.E. The agricultural technology adoption index measures the extent to which agriculture had been adopted by a given country in the given year. The transportation technology adoption index indicates whether human, animals or vehicles were used for transportation. The communications technology adoption index reflects the presence of non-written records and true writing. The existence of pottery is used to measure the country's adoption of industrial technology, and the existence of metalwork and bronze instruments is regarded as an

\footnotetext{
${ }^{8}$ In some cases, however, the history of a country’s current population and the history of that country are substantially different, due to extensive population migration. It is also worth noting that the main empirical results of this paper are unchanged even without adjusting the historical variables for population migration, as shown in Appendix C.
} 
indicator of the adoption of military technology. Each of the overall technology adoption indices denotes the country's average adoption level across these sectors, and is expressed in interval form, as [0,1]. Comin, Easterly and Gong (2010) use Peregrine’s (2003) study as the main source of data for 1000 B.C.E. and 1 C.E. As Comin, Easterly and Gong (2010) use more than 170 source materials to construct the data for 1500 C.E., the technology-adoption index for 1500 C.E. has a more detailed classification for each type of technology. For example, transportation technology is classified by the presence of ships of different capabilities, the wheel, the magnetic compass and horse-powered vehicles. Similar to the other historical variables, the technology-adoption indices are adjusted for population migration using the WMM.

\subsection{Genetic Distance}

Genetic distance or $F_{s t}$ distance is also known as the “co-ancestor coefficient”, which we obtained from Spolaore and Wacziarg (2009). It measures genetic differences based on indices of heterozygosity, which measure the probability that two alleles at a given locus selected at random from two populations will be different. If the allele distributions are identical across the two populations, $F_{s t}$ takes a value of 0 ; if the allele distributions differ, $F_{s t}$ is positive. A higher value of $F_{s t}$ represents a larger genetic difference. It is assumed that the diffusion of technology may be more efficient in genetically similar countries. We also assume that England was the most technologically advanced country in 1500 C.E., and thus our genetic distance variables refers to genetic difference between England and each of the other countries in the dataset. ${ }^{9}$ Similar to the other historical variables, this variable is adjusted for population migration using the WMM.

\footnotetext{
${ }^{9}$ Scholars are increasingly linking genetic differences with cultural conditions and political behavior, as well as with the diffusion of technology. In the very long run, cultural formation may also be shaped by genetic
} 


\section{Linking Historical Variables to Macroeconomic Volatility}

\subsection{Descriptive Evidence}

Figure 1 provides a scatterplot of the history of state-level political institutions and output volatility. The diagram depicts a negative relationship between the two variables, which does not appear to be caused by the few outliers in the plot. The line of best fit indicates that countries with longer histories of state-level political institutions tend to experience less output volatility. ${ }^{10}$ Six former command economies (Armenia, Azerbaijan, Bosnia and Herzegovina, Georgia, Serbia, and Tajikistan) show relatively high output volatility (above 0.1) and have long histories of state-level political institutions (above 0.5). Most developed, high-income countries lie in the lower right-hand corner of the diagram, reflecting their low output volatility (below 0.05) and their relatively long histories of state-level political institutions (above 0.6).

[Insert Figure 1 about here]

Figure 2 shows the relationship between the history of state-level political institutions and the frequency of growth breaks for three groups of countries. The first group of countries is defined by a state-history index greater than 0.75 . The countries in the second group have state-history indices in the intermediate range, between 0.25 and 0.75 . The countries in the third group have state-history indices lower than 0.25 . The average state-history indices for the first, second and third groups of countries are $0.85,0.53$, and 0.15 , respectively. As shown in Figure 2, the average numbers of trend-growth breaks for the first, second and third

differences. Therefore, the potential effects of genetic differences on political behavior should not be neglected. See Fowler and Schreiber (2008), among others, for a review of that literature.

${ }^{10}$ The heteroskadastically robust t-statistic for state history is -3.50 in a bivariate regression of output volatility, which is statistically significant at the 0.1 -percent level. 
groups are $0.5,0.63$, and 0.91 , respectively. The countries with the longest state histories have roughly half the average number of trend-growth breaks exhibited by the countries with the shortest state histories (0.5 versus 0.91$)$. Figure 2 thus illustrates the relationship that countries with longer histories of state-level political institutions experience less medium-run trend-growth volatility.

[Insert Figure 2 about here]

\subsection{Econometric Evidence}

Figures 1 and 2 illustrate a negative relationship between the history of state-level political institutions and macroeconomic volatility. However, the observed relationship may result from other, deeper determinants of macroeconomic volatility, such as geography. Macroeconomic volatility may also be affected by other historical variables related to the history of state-level political institutions. In this section, we address these possibilities by determining whether the relationship between state history and macroeconomic volatility is sensitive to the introduction of other control and historical variables to the regressions.

Formally, we consider the following econometric model:

$$
y_{i}=\theta_{1}+\theta_{2} \cdot \text { history }_{i}+\theta_{3} \cdot \boldsymbol{W}_{i}+\mu_{i}
$$

where the dependent variable $y_{i}$ denotes one of the two measures of macroeconomic volatility for country $i$; histor $y_{i}$ is a historical variable; and $\boldsymbol{W}_{\boldsymbol{i}}$ is a vector of the control variables. The residual, $\mu_{i}$, is assumed to be iid. The parameter of special interest is $\theta_{2}$, which provides an estimate of the relationship between a given historical variable and macroeconomic volatility. Clearly, as macroeconomic volatility in a post-war period cannot affect historical variables prior to that period, reverse causality is unlikely to affect the results of Equation (1). However, if certain structural factors are not included in the regression, they may be argued to be responsible for the observed results. Therefore, the potential 
misspecification issue must be fully addressed in Equation (1). Following the recent literature in the area, several structural factors are added to Equation (1) to control for their effects on macroeconomic volatility.

\section{[Insert Table 1 about here]}

Table 1 reports the results of the ordinary least squares (OLS) regression of Equation (1) when macroeconomic volatility is measured by the standard deviation of output growth. Columns 1-6 of Panel A report the results of setting history $y_{i}$ as each of the six historical variables on the right-hand side of Equation (1). These variables are the history of state-level political institutions (column 1), the history of agriculture (column 2), the technologyadoption indices for 1000 B.C.E. (column 3), 1 C.E. (column 4) and 1500 C.E. (column 5), and genetic distance (column 6). Also included in the regressions are absolute latitude, arable-land area (in log form), and dummy variables for tropical regions, landlocked areas, islands, and continents of Africa, Asia and Europe (omitting America and Oceania). We use these geographic variables because climate, humidity, soil conditions, disease environment and market access may directly and/or indirectly affect human motivation, enterprise, agricultural productivity, institutions and trade, which have been shown to be important determinants of growth and volatility. ${ }^{11}$

\footnotetext{
${ }^{11}$ The literature on the effects of geography on economic performance is prolific. It can be divided into two main groups. Some researchers argue that factors such as tropical or landlocked geography directly inhibit growth and development through poor soil quality, a high prevalence of crop pests and parasites, a lack of coal deposits, an infectious-germ ecology, high transport costs, and the inhibition of motivation to work (see, for example, Sachs and Warner, 1995; Bloom and Sachs, 1998). Other authors find strong evidence that these geographical factors (tropics, germs and crops) only indirectly affect country income, through institutional factors (see, for example, Engerman and Sokoloff, 1997; Acemoglu, Johnson and Roberson, 2002; Easterly and Levine, 2003). Island countries have also been found to have better institutions than countries with land borders (Fors, 2014).
} 
Panel A of Table 1 shows that the history of state-level political institutions is the only historical variable with a statistically significant effect on the standard deviation of output growth in post-war periods. The estimate of -0.049 for the state-history variable shown in column 1 has a t-statistic (in absolute values) of 2.93, which is statistically significant at the 1-percent level. This finding indicates that output volatility is reduced by roughly 0.5 percent when the state-history index is increased by 0.1 points. The estimate is also economically large, because the presence of state history explains almost all of the crosscountry average output volatility (the average standard deviation for output growth is 5.38 percent across all of the countries in the sample). The value of $R^{2}$ in column 1 is 17 percent, which is substantially larger than the values of other $R^{2}$ in Panel A, suggesting that the history of state-level political institutions has much larger explanatory power of output volatility than other historical variables. Also, Panel A, Table 1, shows that being an island country is estimated to reduce output volatility significantly in Column 1, 4, 5 and 6. Moreover, African and Asian countries consistently show higher output volatility compared to the rest of the world.

Panel B of Table 1 displays the results of adding another historical variable to the regression when the regression already includes the history of state-level political institutions and the baseline control variables. Column 1 of Panel B, Table 1 shows that the estimate for state history increases from -0.049 to -0.057 and remains statistically significant at the 1percent level when both state history and agricultural history are included in the regression. The effect of agricultural history is estimated at 3.16e-06, with a t-statistic of 1.86, indicating that output volatility increases by around 0.32 percent for every 1,000 years of agricultural history. However, it is worth noting that the correlation between state history and agricultural history is moderately high (with a correlation coefficient of 0.68 ), which makes it fairly difficult to separate the effects of these two historical variables. Similarly, the results in 
columns 2, 3, 4 and 5 of Panel B, Table 1 show that the estimate for the history of state-level political institutions remains roughly the same and is statistically significant regardless of whether other historical variables are added to the regression. However, the other historical variables are of little statistical significance, suggesting that state history is the most important historical variable explaining output volatility in post-war periods.

If all of the historical variables are considered to be closely related, and collectively to reflect a country's historical development, combining the historical variables to produce a single variable is justified (Ang, 2013). ${ }^{12}$ Column 6 of Panel B, Table 1 shows the results of using the first principal component (FPC) of all of the historical variables to explain output volatility in post-war periods. ${ }^{13}$ The result shows that the estimate for the first principal component of all the historical variables is negative and statistically significant at the 5percent level. This finding supports the claim that countries with long histories of development experience lower output volatility today.

\section{[Insert Table 2 about here]}

The OLS results provided in Table 1 show that on average a strong negative relationship is observed between state history and output volatility. These results, however, do not tell us whether the effect of state history on output volatility is more important for certain countries than the others. Thus, we ask not only the question, 'does state history matters for output volatility?', but also ask the other question, 'for which group of countries state history matters most?’

\footnotetext{
${ }^{12}$ The correlation coefficients of the six historical variables are presented in Table D.1, Appendix D. The results show that the six historical variables are all significantly correlated at the 1-percent level.

${ }^{13}$ Table D.2 in Appendix D reports the explanatory power of each principal component of the historical variables. The first principal component accounts for 67 percent of the variation in the historical variables.
} 
The quantile regression results shown in Table 2 indicate that the strength of the relationship between state history and output volatility increases from the bottom to the top of the conditional distribution. At the 0.05 quantile, the relationship is estimated as -0.025 , which is statistically significant but less than the OLS estimate of -0.049 . From the 0.25 quantile to the 0.50 quantile and thence to the 0.75 quantile, the estimated relationship increases from -0.027 to -0.029 to -0.057 , all of which are statistically significant at the conventional levels. The estimated relationship at the 0.75 quantile is almost twice that estimated at the 0.25 quantile. These results reveal that state history matters most for countries with relatively high volatility. The results also imply that it may be difficult for low-income developing countries to reduce their output volatility if much of their volatility is the result of being an inexperienced state.

\section{[Insert Table 3 about here]}

The results reported in Table 1 and 2 are generated from OLS and quantile regressions in which the standard deviation of output growth is used as the dependent variable. We now seek to confirm that the principal finding is not caused either by our use of the standard deviation of output growth to measure macroeconomic volatility, or by the OLS methodology. Table 3 reports the results of our probit regression of Equation (1) when macroeconomic volatility is measured in terms of the occurrence of trend-growth breaks. Column 1 of Panel A, Table 3 shows that the estimated marginal effect of state history on the occurrence of trend-growth breaks is -0.559 , with a t-statistic of 1.82 , which is statistically significant at the 10-percent level. This finding suggests that countries with short or no histories of state-level political institutions are roughly 56 percent more likely to experience at least one major trend-growth break than countries with long histories of state-level political institutions. Columns 2 and 4 of Panel A, Table 3 show, respectively, that agricultural history and the technology-adoption index in 1 C.E. have a statistically significant negative effect on the 
likelihood of experiencing a trend-growth break. In particular, the technology-adoption index in 1 C.E. has the most statistically significant marginal effect: it is estimated at -0.497 , with a t-statistic of 4.04. This estimate indicates that a country with full technological adoption in 1 C.E. (technology-adoption index of 1) is roughly 50 percent less likely to experience a trendgrowth break today than countries in which little or no technology had been adopted in 1 C.E.

Panel B of Table 3 reports the results of adding another historical variable to a probit regression that already includes the technology-adoption index for 1 C.E. and the baseline control variables. The estimated marginal effect of the technology-adoption index in 1 C.E. remains highly statistically significant across columns 1 to 5 of Panel B, Table 3, whereas the estimated marginal effects of the other historical variables are not statistically significant. These results suggest that the technology-adoption index in 1 C.E. is the most important historical variable affecting the occurrence of trend-growth breaks in a post-war period.

Thus far, we have described the introduction of separate historical variables to the regression of the occurrence of trend-growth breaks. In practice, however, the historical variables are correlated. In the appendix, we show that the first principal component of the six historical variables explains about two thirds of the variation in all of the historical variables. In column 6 of Panel B, Table 3, we thus present the results of the regression when all of the six historical variables are replaced by the FPC. The estimated marginal effect of the FPC is -0.145 , with a t-statistic of 2.89 , which is statistically significant at the 1-percent level. This estimate suggests that countries with longer histories of development are less likely to experience trend-growth breaks.

Appendix B reports the results of various robustness checks, such as excluding African countries from the regression, adding 15 climate and soil variables as controls, and controlling for European population, ethnic fractionalization, democratic institutions and current income. The purpose of these exercises is to check whether our principal finding - the 
significant influence of historical variables on modern macroeconomic volatility-is altered by varying the sample or the control variables. Reassuringly, we find that our principal result is largely unaffected after all of the robustness checks.

In sum, the results presented in this section indicate that historical variables in the collective have a highly significant influence on macroeconomic volatility, measured as either the standard deviation of output growth or the occurrence of trend-growth breaks. Thus, countries with long histories of development are shown to experience more stable growth. When the six historical variables are considered separately, however, only the history of state-level political institutions is found to significantly affect both the standard deviation of output growth and the occurrence of trend-growth breaks. The technology-adoption index in 1 C.E. is found to have a highly significant effect on the occurrence of growth breaks (which captures medium-term shocks), but not on the standard deviation of output growth (which captures short-term shocks).

\section{Channels for the Influence of State History}

Having established in the previous section that state history is a fundamental determinant of macroeconomic volatility today, we now investigate the mechanisms by which state history influences volatility. More specifically, this section presents evidence for linking certain covariates of output volatility with state history, and shows that collectively, these covariates of output volatility explain most if not all of the influence of state history on output volatility.

\subsection{OLS-Regression Results}

There are already a host of covariates of output volatility established in the literature, which include variables such as discretionary fiscal policy, diversification, exchange rate, political constraints on executive power, financial development, FDI inflow, inflation, 
productivity change, political stability, term-of-trade shocks, trade and more. To identify the relevant proximate factors, it suffices to determine the relationship between state history and each of these well-known covariates, and the relationship of each of the covariates with output volatility. The following four covariates of output volatility are found to be significantly related to state history: political stability, discretionary fiscal policy, financial development and foreign direct investment. As shown below, all of these variables are both significantly correlated with output volatility and significantly affected by state history.

[Insert Table 4 about here]

We use the Political Risk Index values for 2000 provided by the International Country Risk Guide to measure political stability. The index ranges from 0 to 1 , where 1 indicates perfect stability. Column 1 of Panel B, Table 4 shows that political stability is significantly affected by state history, which has an estimated effect of 0.135 and a t-statistic of 2.19. This finding suggests that countries with longer histories of state-level political institutions tend to be more politically stable.

The second covariate found to be greatly affected by state history is discretionary fiscal policy. Following Fatás and Mihov (2003), we use the term “discretionary fiscal policy” to describe changes in fiscal policy that do not reflect a reaction to economic conditions. ${ }^{14}$ As shown in column 2 of Panel B, Table 4, the effect of state history on discretionary fiscal policy is estimated at -0.095 , with a t-statistic of 2.57 . This estimate confirms our expectation that countries with longer state histories exhibit less discretion in fiscal policy.

\footnotetext{
${ }^{14}$ Formally, discretionary fiscal policy is measured as the residual, $\epsilon_{i, t}$, of the regression $\Delta G_{i, t}=\alpha_{i}+\beta_{i} \Delta Y_{i, t}+$ $\gamma_{i} \Delta G_{i, t-1}+\delta_{i} W_{i, t}+\epsilon_{i, t}$, where $\Delta G_{i, t}$ denotes the changes in the fiscal policy of country $i$ at time $t, \Delta Y_{i, t}$ is the growth of per-capita GDP, $\Delta G_{i, t-1}$ denotes the lagged changes in fiscal policy at $t-1$, and $W_{i, t}$ is the vector of the control variables. More details on the construction of this variable can be found in Appendix A.
} 
In columns 3 and 4 of Panel B, Table 4, we show that both financial development and FDI inflow are significantly affected by state history. Financial development is measured as the average annual ratio of credit provided by private-sector financial intermediaries (banks and non-banks) to GDP, and FDI inflow is the average annual ratio of inward foreign direct investment to GDP. The estimated effects of state history on financial development and FDI are $70.122(\mathrm{t}$-statistic $=3.36)$ and $3.724(\mathrm{t}$-statistic $=2.49)$, respectively. These estimates are highly significant, and indicate that countries with longer histories of state-level political institutions are more financially developed and receive greater FDI inflow.

Together, these results show that there is no unique channel through which state history affects output volatility. Instead, the effects of state history on output volatility are multidimensional, operating principally via political and financial frameworks. A lengthy state history reduces the degree of political risk and enhances political constraints on fiscalpolicy discretion. It also facilitates financial development and attracts FDI. The results shown in columns 1 to 4 of Panel A, Table 4 also confirm the claim made by previous researchers that political stability, discretionary fiscal policy, financial development and FDI inflow are all important covariates of output volatility today. Our estimates of the effects of these covariates not only have the expected signs, but are highly significant. ${ }^{15}$

Clearly, the four covariates of output may not be independent in practice. For instance, a sudden decrease in political stability may lead to a decrease in FDI inflow, requiring the government to impose a discretionary fiscal policy. This will in turn increase political instability. Therefore, we again replace the four output covariates with their first principal component. ${ }^{16}$ Column 5 of Panel B, Table 4 shows that state history has a highly

\footnotetext{
${ }^{15}$ The only exception is the political-stability variable, which is statistically significant at the 10-percent level.

${ }^{16}$ Table D.3 in Appendix D displays the correlation-coefficient matrix of the four covariates, and Table D.4 details the explanatory power of each of the four principal components. Political volatility, discretionary fiscal
} 
significant effect on the FPC. In turn, the FPC is found to significantly affect output volatility $(-0.004$, t-statistic $=2.21)$, as shown in column 5 of Panel A, Table 4.

The next question is whether there are other channels through which state history affects output volatility. The results displayed in column 6 of Table 4 indicate that the highly statistically significant effect of state history on output volatility $(-0.049$, t-statistic $=2.93)$ shown in Panel B disappears when the FPC of the covariates is added to the regression $(0.002$, t-statistic $=0.13)$, as shown in Panel A. The estimate of the FPC of the four covariates $(-0.004)$ remains unchanged, and is still statistically significant at conventional levels (tstatistic $=1.83)$. Thus, we can safely conclude that state history influences output volatility through the channels of political stability, discretionary fiscal policy, financial development and FDI inflow.

\subsection{Instrumental Variable Regression Results and Further Robustness Checks}

We have shown that a statistically important relationship exists between state history and output volatility, and that the influence of state history on output volatility is mediated by four output covariates. Nevertheless, the four covariates shown to be highly correlated with output volatility may themselves be determined by output volatility. To establish causality, therefore, it is necessary to find a source of exogenous variation in the four covariates of output volatility. We use state history, among other variables, as a key instrument for the FPC of the four covariates of output volatility in instrumental-variable regressions. State history appears to be a good instrument because it is exogenous and has been shown to be highly correlated with each of the four covariates of output volatility, either individually or collectively. In addition, state history is a valid instrument if it satisfies the exclusion

policy and financial development are correlated at the 1-percent level of significance. In addition, the first principal component of the four covariates accounts for nearly 50 percent of their total variation. 
restriction; that is, if it only indirectly affects output volatility through the four covariates. In the following instrumental-variable regressions, we subject our instruments to various tests.

\section{[Insert Table 5 about here]}

Table 5 shows the results of two-stage least squares instrumental variable regressions in which both state history and agricultural history are used as instruments. ${ }^{17}$ The results of the second-stage regression are reported in Panel A, and those of the first-stage regression are provided in Panel B. The first-stage results show that state history is highly significant in explaining the FPC of the four covariates, whereas agricultural history is only marginally significant across the different controls specified in columns 1 to 5 . In column 1 , when only the baseline controls are added to the first- and second-stage regressions, the instrumented FPC of the four covariates is estimated to have a stabilizing effect on output volatility. This effect is statistically significant at the 10 -percent level $(-0,007$, t-statistic $=1.89)$. More importantly, state history and agricultural history appear to be appropriate instruments for the FPC of the four covariates, as shown by the F-statistic for the joint significance of the excluded instruments and the results of both the Kleibergen and Paap under-identification test and the Sargan-Hansen over-identification test. The F-statistic $(8.03$, p-value $=0.001)$ indicates that state history and agricultural history have significant explanatory power for the FPC of the four covariates. The results of the Kleibergen and Paap under-identification test $(p$-value $=0.002)$ do not lead us to reject the null hypothesis that the equation is underidentified; the model is thus identified, and the excluded instruments are relevant. The results of the Sargan-Hansen over-identification test $(\mathrm{p}$-value $=0.101)$ do not lead us to reject the

\footnotetext{
${ }^{17}$ We use soil type as an additional instrument, along with state history, and obtain regression results fairly similar to those for state history and agricultural history. To save space, the results for soil type are not shown here, but can be provided upon request.
} 
joint null hypothesis that the instruments are valid instruments (that is, they are uncorrelated with the error term, and that they are correctly excluded from the estimated equation).

More controls are progressively added to the baseline model, as shown in the remaining columns of Table 5. Column 2 shows the results of adding dummies for British, French, and Spanish colonies (other European colonies are the omitted group); column 3 displays the results of adding an index of malaria prevalence; the results in column 4 reflect the proportion of Protestants in the population; and column 5 shows the results of excluding neo-Europes (Australia, Canada, New Zealand, and the U.S.). Clearly, the identity of the colonizer is important, because the difference between a civil-law and common-law legal system may affect a country’s economic outcomes (La Porta et al., 1997). The type of legal system in place may also create important cross-country differences in terms of institutional legacy and human-capital policies, which also affect economic outcomes (Acemoglu, Johnson and Robinson, 2001). Disease ecology may directly affect economic outcomes by reducing productivity and household savings. It has also been shown to have an indirect influence on the institutional framework set up by colonizers. Acemoglu, Gallego and Robinson (2014) find that Protestant missionary activity in the early $20^{\text {th }}$ century is a source of exogenous variation in human capital. As the proportion of Protestants in a country's population today can be linked to missionary activity in the early $20^{\text {th }}$ century, it may affect human-capital formation and economic outcomes. Finally, the neo-Europes listed above share a colonial heritage and level of institutional development that differ from those of the rest of the world. We thus determine whether our results are sensitive to the exclusion of these countries from the regression.

Columns 2 to 5 of Table 5 show that adding more controls to the model only increases the estimated effect of the FPC of the four covariates on output volatility. When colonial origins are added to the model, as shown in column 2, the estimated effect of the FPC 
increases from $-0,007$ to -0.011 , which is statistically significant at the 1-percent level (tstatistic $=2.90)$. Similarly, when an index of malaria prevalence is added to the model (as shown in column 3), the estimated effect of the FPC increases to -0.014 (t-statistic $=2.33$ ). As shown in column 5, the estimated effect of the FPC is still -0.014 and statistically significant after adding all of the above-mentioned controls. The results of the first-stage regressions listed in Panel B show that state history continues to be highly significant in explaining the FPC of the four covariates, even when more controls are added, whereas agricultural history is only marginally significant at best. The F-statistic in column 5 is considerably smaller than that in column 2, falling from 8.43 to 3.43 . However, the results of the Kleibergen and Paap under-identification test $(p$-value $=0.035)$ confirm that the instruments are still relevant. Moreover, state history and agricultural history remain valid instruments, according to the results of the Sargan-Hansen over-identification test (p-value = $0.203)$.

[Insert Table 6 about here]

Compared with the 2SLS estimator, the LIML estimator has been shown to yield less bias and confidence intervals with better rates (Stock, Wright, and Yogo, 2002). In addition, when the estimates and standard errors generated by the LIML estimator are similar to those produced by the 2SLS estimator, the estimates are unlikely to be driven by weak-instrument problems (Angrist and Pischke, 2008). For comparison, we re-estimate all of the regressions reported in Table 6 using the LIML estimator, and provide the results in Table 6. All of the estimates and standard errors (t-statistics) generated by the LIML estimator are very similar to those produced by the 2SLS estimator, as shown in Table 5. Moving from column 1 to column 5 of Table 6, the LIML estimates of the effects of the FPC of the four covariates on output volatility are $-0.008,-0.011,-0.015,-0.015$ and -0.016 , respectively, and their corresponding t-statistics (in absolute values) are 1.76, 2.81, 2.26, 2.13 and 1.94. 
Reassuringly, as these estimates and t-values are very close to those produced by the 2SLS estimator (shown in Table 5), weak-instrument problems are unlikely to drive our results. In addition, Sargan-Hansen over-identification tests comfortably fail to reject the null hypothesis that the instruments are valid across all of the columns in Table 6 .

In sum, we attempt in this section to identify the mechanisms by which state history affects output volatility today. First, we use OLS regressions to show that state history is linked to political stability, discretionary fiscal policy, financial development and FDI inflow, and that these variables are in turn linked to output volatility. Second, we use both 2SLS and LIML estimators to confirm that these relationships are causal and insensitive to the inclusion of additional controls.

\section{Discussion and Conclusions}

This study is motivated by recent research showing that historical variables have a critical role in explaining current economic performance. While most studies in this area investigate differences in income level or income inequality, we take a step further to examine whether and how historical variables affect macroeconomic volatility, measured either by highfrequency output volatility or by medium-run trend-growth breaks. The results of the study contribute to the ongoing debate regarding the fundamental determinants of macroeconomic volatility.

We find that of the six historical variables previously shown to be important determinants of income, only the history of state-level political institutions significantly affects both the high-frequency output volatility and the occurrence of medium-run trendgrowth breaks. The other historical variables found to affect medium-run trend-growth breaks, but not high-frequency output volatility, are agricultural history and the adoption of technology in 1 C.E. Thus, the historical variables do not all provide equally important 
explanations of macroeconomic volatility, despite their important roles in determining differences in income, as shown in previous studies. We also find that the state history variable is more important in countries with a higher level of macroeconomic volatility. In addition, this study highlights the channels by which macroeconomic volatility is influenced by state history. Using both OLS and instrumental-variable techniques, and adding various controls examined in recent studies, we show that long-standing states are more politically stable, less likely to engage in discretionary fiscal policy, and exhibit higher levels of financial development and FDI inflow. These results are consistent with the predictions that long-standing states process a higher stock of social capital, which helps them to prevent civil wars and other forms of political instability. In addition, a politically stable environment may reduce the incentive to implement discretionary fiscal policies. A well-developed financial system and high FDI inflow are consistent with political stability and effective state administration and control. In sum, the findings of this study support the hypothesis that longstanding states have distinct advantages over newly established states in reducing macroeconomic instability. 
Figure 1: Scatterplot of State History and Output Volatility

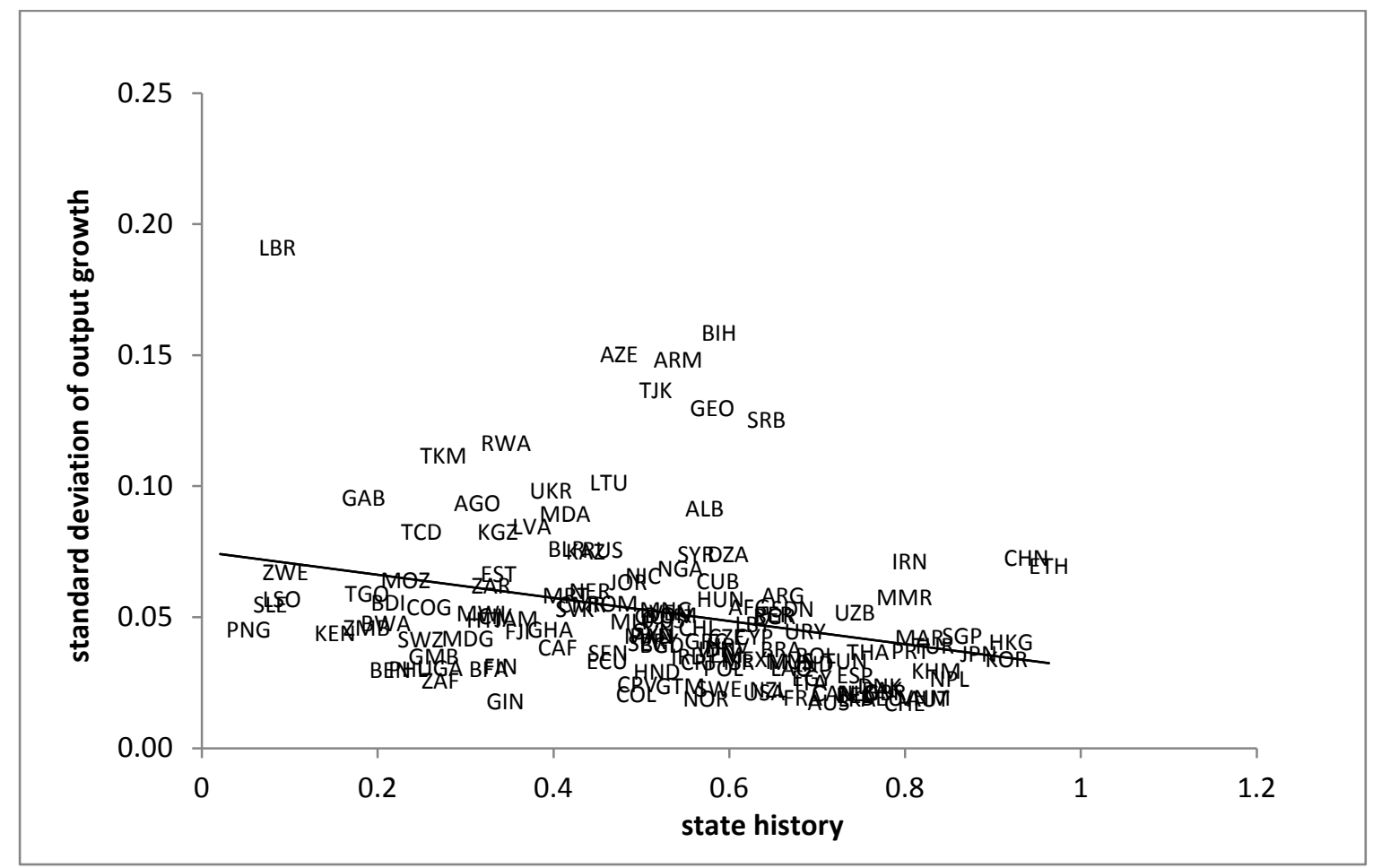

Notes: See Section 2 in text for discussions of state history and output volatility.

Figure 2: State History and Frequency of Trend-Growth Breaks

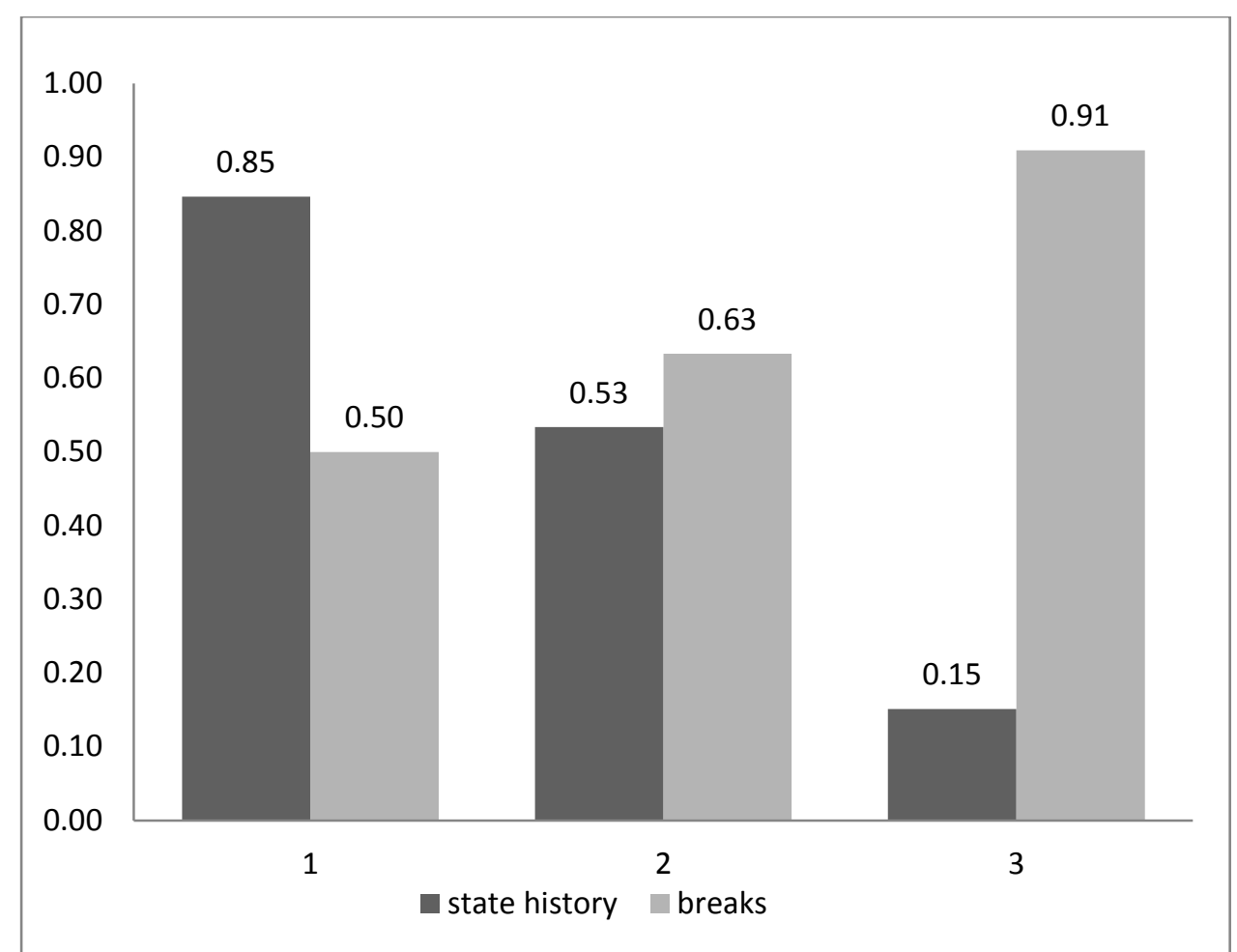

Notes: See Section 2 in text for discussions of state history and trend-growth breaks (breaks). 
Table 1: Historical Variables and Volatility of Output Growth (OLS Regressions)

\begin{tabular}{|c|c|c|c|c|c|c|}
\hline \multicolumn{7}{|c|}{ Dependent variable is the standard deviation of annual output growth (1960-2011) } \\
\hline \multicolumn{7}{|c|}{ Panel A } \\
\hline & 1 & 2 & 3 & 4 & 5 & 6 \\
\hline State history & $\begin{array}{c}-0.049 * * * \\
(2.93)\end{array}$ & & & & & \\
\hline Agri. history & & $\begin{array}{c}5.13 e-7 \\
(0.29)\end{array}$ & & & & \\
\hline $\begin{array}{l}\text { Technology } \\
\text { 1000BC }\end{array}$ & & & $\begin{array}{l}0.008 \\
(0.88)\end{array}$ & & & \\
\hline $\begin{array}{l}\text { Technology } \\
\text { 1CE }\end{array}$ & & & & $\begin{array}{l}-0.007 \\
(0.92)\end{array}$ & & \\
\hline $\begin{array}{l}\text { Technology } \\
\text { 1500CE }\end{array}$ & & & & & $\begin{array}{l}-0.011 \\
(0.80)\end{array}$ & \\
\hline $\begin{array}{l}\text { Genetic } \\
\text { distance }\end{array}$ & & & & & & $\begin{array}{c}4.74 \mathrm{e}-6 \\
(0.77)\end{array}$ \\
\hline $\begin{array}{l}\text { Absolute } \\
\text { latitude }\end{array}$ & $\begin{array}{l}0.000 \\
(0.64)\end{array}$ & $\begin{array}{l}0.000 \\
(0.96)\end{array}$ & $\begin{array}{l}0.000 \\
(0.65)\end{array}$ & $\begin{array}{l}0.001^{*} \\
(1.77)\end{array}$ & $\begin{array}{l}0.000 \\
(0.19)\end{array}$ & $\begin{array}{l}0.000 \\
(0.85)\end{array}$ \\
\hline Tropics & $\begin{array}{l}0.001 \\
(0.07)\end{array}$ & $\begin{array}{l}0.007 \\
(0.93)\end{array}$ & $\begin{array}{l}0.007 \\
(0.79)\end{array}$ & $\begin{array}{l}0.004 \\
(0.41)\end{array}$ & $\begin{array}{l}-0.003 \\
(0.27)\end{array}$ & $\begin{array}{l}0.004 \\
(0.43)\end{array}$ \\
\hline $\begin{array}{l}\text { Log of } \\
\text { arable land }\end{array}$ & $\begin{array}{l}-0.000 \\
(0.23)\end{array}$ & $\begin{array}{l}-0.002 \\
(1.02)\end{array}$ & $\begin{array}{l}-0.001 \\
(0.57)\end{array}$ & $\begin{array}{c}-0.003^{* *} \\
(2.06)\end{array}$ & $\begin{array}{l}-0.002 \\
(1.37)\end{array}$ & $\begin{array}{l}-0.002 \\
(0.87)\end{array}$ \\
\hline Landlocked & $\begin{array}{l}0.001 \\
(0.00)\end{array}$ & $\begin{array}{l}0.002 \\
(0.26)\end{array}$ & $\begin{array}{l}0.005 \\
(0.79)\end{array}$ & $\begin{array}{l}-0.007 \\
(1.05)\end{array}$ & $\begin{array}{l}-0.008 \\
(1.12)\end{array}$ & $\begin{array}{l}0.000 \\
(0.05)\end{array}$ \\
\hline Island & $\begin{array}{c}-0.010^{*} \\
(1.89)\end{array}$ & $\begin{array}{l}-0.009 \\
(1.65) \\
\end{array}$ & $\begin{array}{l}-0.004 \\
(0.53) \\
\end{array}$ & $\begin{array}{c}-0.015^{* * *} \\
(2.81)\end{array}$ & $\begin{array}{c}-0.015^{* *} \\
(2.35) \\
\end{array}$ & $\begin{array}{c}-0.009 * \\
(1.98) \\
\end{array}$ \\
\hline Africa & $\begin{array}{l}0.004 \\
(0.80)\end{array}$ & $\begin{array}{c}0.014^{* *} \\
(2.11)\end{array}$ & $\begin{array}{c}0.013^{* *} \\
(2.29)\end{array}$ & $\begin{array}{c}0.016^{* * *} * \\
(2.81)\end{array}$ & $\begin{array}{c}0.014 * * \\
(2.16)\end{array}$ & $\begin{array}{l}0.009 \\
(1.29) \\
\end{array}$ \\
\hline Asia & $\begin{array}{c}0.012 * * \\
(2.13)\end{array}$ & $\begin{array}{l}0.007 \\
(1.28)\end{array}$ & $\begin{array}{l}0.007 \\
(1.19)\end{array}$ & $\begin{array}{c}0.019 * * * \\
(2.77)\end{array}$ & $\begin{array}{l}0.013 \\
(1.52) \\
\end{array}$ & $\begin{array}{l}0.006 \\
(1.15)\end{array}$ \\
\hline Europe & $\begin{array}{l}0.000 \\
(0.03)\end{array}$ & $\begin{array}{l}-0.001 \\
(0.08) \\
\end{array}$ & $\begin{array}{l}-0.001 \\
(0.15) \\
\end{array}$ & $\begin{array}{c}-0.009 \\
(1.10) \\
\end{array}$ & $\begin{array}{l}0.001 \\
(0.11) \\
\end{array}$ & $\begin{array}{l}-0.000 \\
(0.00)\end{array}$ \\
\hline Observations & 117 & 117 & 102 & 122 & 114 & 117 \\
\hline$R^{2}$ & 0.17 & 0.07 & 0.07 & 0.14 & 0.10 & 0.08 \\
\hline \multicolumn{7}{|c|}{ Panel B } \\
\hline & $\begin{array}{c}\text { Agri. } \\
\text { history }\end{array}$ & $\begin{array}{c}\text { Technology } \\
\text { 1000BC }\end{array}$ & $\begin{array}{c}\text { Technology } \\
\text { 1CE }\end{array}$ & $\begin{array}{c}\text { Technology } \\
\text { 1500CE }\end{array}$ & $\begin{array}{l}\text { Genetic } \\
\text { distance }\end{array}$ & $\begin{array}{l}\text { FPC of } \\
\text { history }\end{array}$ \\
\hline State history & $\begin{array}{c}-0.057 * * * \\
(3.24) \\
\end{array}$ & $\begin{array}{c}-0.052^{* * *} \\
(3.15)\end{array}$ & $\begin{array}{c}-0.045^{* *} \\
(2.59) \\
\end{array}$ & $\begin{array}{c}-0.050^{* *} \\
(2.61) \\
\end{array}$ & $\begin{array}{c}-0.054^{* * *} \\
(2.67) \\
\end{array}$ & \\
\hline $\begin{array}{l}\text { Column } \\
\text { variable }\end{array}$ & $\begin{array}{c}3.16 \mathrm{e}-06^{*} \\
(1.86)\end{array}$ & $\begin{array}{l}0.014 * \\
(1.67)\end{array}$ & $\begin{array}{l}-0.002 \\
(0.25)\end{array}$ & $\begin{array}{l}0.009 \\
(0.80)\end{array}$ & $\begin{array}{c}-4.73 e-06 \\
(0.60)\end{array}$ & $\begin{array}{c}-0.004^{* *} \\
(2.06)\end{array}$ \\
\hline $\begin{array}{l}\text { Baseline } \\
\text { controls }\end{array}$ & Yes & Yes & Yes & Yes & Yes & Yes \\
\hline Observations & 117 & 98 & 113 & 105 & 117 & 113 \\
\hline$R^{2}$ & 0.19 & 0.21 & 0.18 & 0.19 & 0.18 & 0.12 \\
\hline
\end{tabular}

Notes:

1. *** indicates significance at the 1-percent level, ** at the 5-percent level, and * at the 10 -percent level.

2. Absolute values of heteroskasdastically robust t-statistics are in the parentheses. All regressions include an unreported constant.

3. Baseline controls include absolute latitude, logged arable land area, and dummies for tropics, landlocked, island, Africa, Asia and Europe. FPC is the first principal component of historical variables.

4. See Section 2 in text and Data Appendix for discussions of the variables. 
Table 2: State History and Volatility of Output Growth (Quantile Regressions)

\begin{tabular}{|l|c|c|c|c|c|}
\hline \multicolumn{5}{|c|}{ Dependent variable is the standard deviation of annual output growth (1960-2011) } \\
\cline { 2 - 6 } & OLS & 0.05 & 0.25 & 0.50 & 0.75 \\
\hline State history & $-0.049^{* * *}$ & $-0.025^{*}$ & $-0.027^{* * *}$ & $-0.029^{* *}$ & $-0.057^{* * *}$ \\
& $(2.93)$ & $(1.88)$ & $(2.66)$ & $(1.82)$ & $(2.64)$ \\
\hline Absolute & 0.000 & 0.000 & 0.000 & 0.000 & 0.000 \\
latitude & $(0.64)$ & $(0.60)$ & $(0.16)$ & $(0.91)$ & $(0.31)$ \\
\hline Tropics & 0.001 & 0.001 & 0.004 & 0.004 & 0.005 \\
& $(0.07)$ & $(0.11)$ & $(0.41)$ & $(0.58)$ & $(0.33)$ \\
\hline Log of & -0.000 & -0.001 & -0.000 & 0.000 & 0.003 \\
arable land & $(0.23)$ & $(0.66)$ & $(0.24)$ & $(0.02)$ & $(1.03)$ \\
\hline Landlocked & 0.001 & 0.008 & 0.001 & 0.001 & -0.007 \\
& $(0.00)$ & $(1.33)$ & $(0.20)$ & $(0.10)$ & $(0.65)$ \\
\hline Island & $-0.010^{*}$ & -0.001 & 0.001 & -0.001 & -0.013 \\
& $(1.89)$ & $(0.27)$ & $(0.16)$ & $0.21)$ & $(0.98)$ \\
\hline Africa & 0.004 & -0.004 & 0.006 & 0.005 & 0.001 \\
& $(0.80)$ & $(0.55)$ & $(1.05)$ & $(0.98)$ & $(0.09)$ \\
\hline Asia & $0.012 * *$ & 0.002 & 0.008 & 0.004 & 0.013 \\
& $(2.13)$ & $(0.49)$ & $(1.59)$ & $(0.72)$ & $(1.63)$ \\
\hline Europe & 0.000 & -0.013 & -0.001 & -0.014 & 0.002 \\
& $(0.03)$ & $(1.00)$ & $(0.10)$ & $(1.38)$ & $(0.12)$ \\
\hline Observations & 117 & 117 & 117 & 117 & 117 \\
\hline$R^{2}$ & 0.17 & 0.10 & 0.13 & 0.10 & 0.10 \\
\hline
\end{tabular}

Notes:
$1 . \quad * * *$ indicates significance at the 1 -percent level, $* *$ at the 5-percent level, and * at the 10 -percent level.

2. Absolute values of heteroskasdastically robust t-statistics are in the parentheses for OLS, and bootstrapped for quantiles.

3. All regressions include an unreported constant.

4. See Section 2 in text and Appendix A for discussions of the variables. 
Table 3: Historical Variables and Trend-Growth Breaks (Probit Regressions)

\begin{tabular}{|c|c|c|c|c|c|c|}
\hline \multicolumn{7}{|c|}{ Dependent variable is a dummy variable indicating the presence of trend-growth breaks } \\
\hline \multicolumn{7}{|c|}{ Panel A } \\
\hline & 1 & 2 & 3 & 4 & 5 & 6 \\
\hline State history & $\begin{array}{c}-0.559 * \\
(1.82)\end{array}$ & & & & & \\
\hline Agri. history & & $\begin{array}{c}-7.94 \mathrm{e}-5^{*} \\
(1.77)\end{array}$ & & & & \\
\hline $\begin{array}{l}\text { Technology } \\
\text { 1000BC }\end{array}$ & & & $\begin{array}{l}-0.075 \\
(0.36)\end{array}$ & & & \\
\hline $\begin{array}{l}\text { Technology } \\
\text { 1CE }\end{array}$ & & & & $\begin{array}{c}-0.497 * * * \\
(4.04)\end{array}$ & & \\
\hline $\begin{array}{l}\text { Technology } \\
\text { 1500CE }\end{array}$ & & & & & $\begin{array}{l}-0.088 \\
(0.26)\end{array}$ & \\
\hline $\begin{array}{l}\text { Genetic } \\
\text { distance }\end{array}$ & & & & & & $\begin{array}{c}1.82 \mathrm{e}-4 \\
(1.38)\end{array}$ \\
\hline $\begin{array}{l}\text { Absolute } \\
\text { latitude }\end{array}$ & $\begin{array}{l}0.006 \\
(0.70)\end{array}$ & $\begin{array}{l}0.000 \\
(0.05)\end{array}$ & $\begin{array}{l}0.004 \\
(0.44)\end{array}$ & $\begin{array}{l}0.005 \\
(0.65)\end{array}$ & $\begin{array}{l}0.002 \\
(0.24)\end{array}$ & $\begin{array}{l}0.005 \\
(0.56)\end{array}$ \\
\hline Tropics & $\begin{array}{l}0.238 \\
(1.04)\end{array}$ & $\begin{array}{l}0.083 \\
(0.35)\end{array}$ & $\begin{array}{l}0.238 \\
(0.95)\end{array}$ & $\begin{array}{l}0.159 \\
(0.76)\end{array}$ & $\begin{array}{l}0.163 \\
(0.63)\end{array}$ & $\begin{array}{l}0.174 \\
(0.74)\end{array}$ \\
\hline $\begin{array}{l}\text { Log of } \\
\text { arable land }\end{array}$ & $\begin{array}{c}0.062^{* *} \\
(2.12)\end{array}$ & $\begin{array}{l}0.049^{*} \\
(1.68)\end{array}$ & $\begin{array}{l}0.029 \\
(0.83)\end{array}$ & $\begin{array}{c}0.057 * * \\
(2.24)\end{array}$ & $\begin{array}{l}0.034 \\
(1.16)\end{array}$ & $\begin{array}{l}0.052^{*} \\
(1.89)\end{array}$ \\
\hline Landlocked & $\begin{array}{l}-0.054 \\
(0.47)\end{array}$ & $\begin{array}{l}-0.093 \\
(0.78)\end{array}$ & $\begin{array}{l}0.020 \\
(0.15)\end{array}$ & $\begin{array}{l}-0.027 \\
(0.25)\end{array}$ & $\begin{array}{l}-0.035 \\
(0.27)\end{array}$ & $\begin{array}{l}-0.109 \\
(0.89)\end{array}$ \\
\hline Island & $\begin{array}{l}-0.057 \\
(0.37)\end{array}$ & $\begin{array}{l}-0.118 \\
(0.71)\end{array}$ & $\begin{array}{l}0.080 \\
(0.31) \\
\end{array}$ & $\begin{array}{l}0.009 \\
(0.06) \\
\end{array}$ & $\begin{array}{l}-0.011 \\
(0.07)\end{array}$ & $\begin{array}{l}-0.045 \\
(0.30)\end{array}$ \\
\hline Africa & $\begin{array}{l}-0.046 \\
(0.31)\end{array}$ & $\begin{array}{l}-0.128 \\
(0.72)\end{array}$ & $\begin{array}{l}0.011 \\
(0.08)\end{array}$ & $\begin{array}{l}-0.077 \\
(0.59)\end{array}$ & $\begin{array}{l}0.007 \\
(0.04)\end{array}$ & $\begin{array}{l}-0.076 \\
(0.44)\end{array}$ \\
\hline Asia & $\begin{array}{c}0.238^{*} \\
(1.66)\end{array}$ & $\begin{array}{c}0.288^{*} \\
(1.92) \\
\end{array}$ & $\begin{array}{l}0.260 \\
(1.54)\end{array}$ & $\begin{array}{c}0.214^{*} \\
(1.66) \\
\end{array}$ & $\begin{array}{l}0.210 \\
(1.34)\end{array}$ & $\begin{array}{l}0.130 \\
(0.89)\end{array}$ \\
\hline Europe & $\begin{array}{c}0.424^{* *} \\
(2.30)\end{array}$ & $\begin{array}{c}0.494^{* * *} \\
(2.73)\end{array}$ & $\begin{array}{c}0.411^{* *} \\
(2.10)\end{array}$ & $\begin{array}{c}0.477^{* * *} \\
(2.89)\end{array}$ & $\begin{array}{c}0.439 * * \\
(2.39)\end{array}$ & $\begin{array}{c}0.446^{* *} \\
(2.41)\end{array}$ \\
\hline Observations & 94 & 94 & 83 & 95 & 93 & 94 \\
\hline Pseudo $R^{2}$ & 0.13 & 0.13 & 0.09 & 0.20 & 0.09 & 0.12 \\
\hline \multicolumn{7}{|c|}{ Panel B } \\
\hline & $\begin{array}{l}\text { State } \\
\text { history }\end{array}$ & $\begin{array}{c}\text { Agri. } \\
\text { history }\end{array}$ & $\begin{array}{c}\text { Technology } \\
\text { 1000BC }\end{array}$ & $\begin{array}{c}\text { Technology } \\
\text { 1500CE }\end{array}$ & $\begin{array}{l}\text { Genetic } \\
\text { distance }\end{array}$ & $\begin{array}{l}\text { FPC of } \\
\text { history }\end{array}$ \\
\hline $\begin{array}{l}\text { Technology } \\
\text { 1CE }\end{array}$ & $\begin{array}{c}-0.433^{* * *} \\
(3.27)\end{array}$ & $\begin{array}{c}-0.458 * * * \\
(3.31)\end{array}$ & $\begin{array}{c}-0.584^{* * *} \\
(3.17)\end{array}$ & $\begin{array}{c}-0.634^{* * *} \\
(4.34)\end{array}$ & $\begin{array}{c}-0.521 * * * \\
(3.39)\end{array}$ & \\
\hline $\begin{array}{l}\text { Column } \\
\text { variable }\end{array}$ & $\begin{array}{c}-0.306 \\
(0.93)\end{array}$ & $\begin{array}{c}-2.92 \mathrm{e}-5 \\
(0.59)\end{array}$ & $\begin{array}{l}0.303 \\
(1.19)\end{array}$ & $\begin{array}{l}0.430 \\
(1.09)\end{array}$ & $\begin{array}{c}-2.38 \mathrm{e}-5 \\
(0.15)\end{array}$ & $\begin{array}{c}-0.145^{* * *} \\
(2.89)\end{array}$ \\
\hline $\begin{array}{l}\text { Baseline } \\
\text { controls }\end{array}$ & Yes & Yes & Yes & Yes & Yes & Yes \\
\hline Observations & 91 & 91 & 81 & 89 & 91 & 91 \\
\hline Pseudo $R^{2}$ & 0.19 & 0.19 & 0.16 & 0.21 & 0.19 & 0.18 \\
\hline
\end{tabular}

Notes:

1. $* * *$ indicates significance at the 1-percent level, ** at the 5-percent level, and * at the 10-percent level.

2. Absolute values of heteroskasdastically robust t-statistics are in the parentheses.

3. All regressions include an unreported constant.

4. Baseline controls include absolute latitude, logged arable land area, and dummies for tropics, landlocked, island, Africa, Asia and Europe. FPC is the first principal component of historical variables.

5. See Section 2 in text and Appendix A for discussions of the variables. 
Table 4: State History and the Proximate Factors of Output Volatility

\begin{tabular}{|c|c|c|c|c|c|c|}
\hline \multicolumn{7}{|c|}{$\begin{array}{c}\text { Panel A } \\
\text { Dependent variable is the standard devic }\end{array}$} \\
\hline & (1) & $(2)$ & (3) & (4) & (5) & (6) \\
\hline $\begin{array}{l}\text { Political } \\
\text { stability }\end{array}$ & $\begin{array}{c}-0.076^{*} \\
(1.75)\end{array}$ & & & & & \\
\hline $\begin{array}{l}\text { Discretionary } \\
\text { fiscal policy }\end{array}$ & & $\begin{array}{c}0.170 * * * \\
(4.46)\end{array}$ & & & & \\
\hline $\begin{array}{l}\text { Financial } \\
\text { development }\end{array}$ & & & $\begin{array}{c}-1.19 \mathrm{e}-4^{* * *} \\
(3.09)\end{array}$ & & & \\
\hline FDI inflow & & & & $\begin{array}{c}-0.002 * * \\
(2.51) \\
\end{array}$ & & \\
\hline $\begin{array}{l}\text { FPC of prox. } \\
\text { factors }\end{array}$ & & & & & $\begin{array}{c}-0.004^{* *} \\
(2.21)\end{array}$ & $\begin{array}{c}-0.004^{*} \\
(1.83)\end{array}$ \\
\hline State history & & & & & & $\begin{array}{l}0.002 \\
(0.13)\end{array}$ \\
\hline $\begin{array}{l}\text { Baseline } \\
\text { controls }\end{array}$ & Yes & Yes & Yes & Yes & Yes & Yes \\
\hline Observations & 113 & 100 & 104 & 93 & 75 & 72 \\
\hline$R^{2}$ & 0.19 & 0.29 & 0.28 & 0.26 & 0.28 & 0.30 \\
\hline \multicolumn{7}{|c|}{$\begin{array}{c}\text { Panel } B \\
\text { Dependent variables are: }\end{array}$} \\
\hline & $\begin{array}{l}\text { Political } \\
\text { stability }\end{array}$ & $\begin{array}{l}\text { Discretionary } \\
\text { fiscal policy }\end{array}$ & $\begin{array}{c}\text { Financial } \\
\text { development }\end{array}$ & $\begin{array}{c}\text { FDI } \\
\text { inflow }\end{array}$ & $\begin{array}{l}\text { FPC of prox. } \\
\text { factors }\end{array}$ & $\begin{array}{c}\text { Output } \\
\text { volatility }\end{array}$ \\
\hline State history & $\begin{array}{c}0.135^{* *} \\
(2.19)\end{array}$ & $\begin{array}{c}-0.095^{* *} \\
(2.57) \\
\end{array}$ & $\begin{array}{c}70.122 * * * \\
(3.36)\end{array}$ & $\begin{array}{c}3.724 * * \\
(2.49)\end{array}$ & $\begin{array}{c}2.20^{* * *} \\
(3.14)\end{array}$ & $\begin{array}{c}-0.049 * * * \\
(2.93)\end{array}$ \\
\hline $\begin{array}{l}\text { Baseline } \\
\text { controls }\end{array}$ & Yes & Yes & Yes & Yes & Yes & Yes \\
\hline Observations & 104 & 96 & 95 & 85 & 72 & 117 \\
\hline$R^{2}$ & 0.30 & 0.38 & 0.48 & 0.48 & 0.56 & 0.17 \\
\hline
\end{tabular}

Notes:

1. $* * *$ indicates significance at the 1-percent level, ** at the 5-percent level, and * at the 10-percent level.

2. Absolute values of heteroskasdastically robust t-statistics are in the parentheses.

3. All regressions include an unreported constant.

4. Baseline controls include absolute latitude, logged arable land area, and dummies for tropics, landlocked, island, Africa, Asia and Europe. FPC of proximate factors is the first principal component of the four proximate factors of output volatility.

5. See Section 2 in text and Appendix A for discussions of the variables. 
Table 5: 2SLS Instrumental Variable Regressions and Further Robustness Checks

\begin{tabular}{|c|c|c|c|c|c|}
\hline \multicolumn{6}{|c|}{$\begin{array}{c}\text { Panel A: Second-stage regressions } \\
\text { Dependent variable is the standard deviation of annual output growth }\end{array}$} \\
\hline & $(1)$ & $(2)$ & (3) & $(4)$ & (5) \\
\hline $\begin{array}{l}\text { FPC of prox. } \\
\text { factors }\end{array}$ & $\begin{array}{c}-0.007 * \\
(1.89)\end{array}$ & $\begin{array}{c}-0.011 * * * \\
(2.90)\end{array}$ & $\begin{array}{c}-0.014^{* *} \\
(2.33) \\
\end{array}$ & $\begin{array}{c}-0.014^{* *} \\
(2.25) \\
\end{array}$ & $\begin{array}{c}-0.014^{* *} \\
(2.08)\end{array}$ \\
\hline $\begin{array}{l}\text { Kleibergen and } \\
\text { Paap test (p) }\end{array}$ & 0.002 & 0.002 & 0.021 & 0.018 & 0.035 \\
\hline $\begin{array}{l}\text { Over- } \\
\text { identification } \\
\text { test (p) }\end{array}$ & 0.101 & 0.204 & 0.349 & 0.217 & 0.203 \\
\hline \multicolumn{6}{|c|}{$\begin{array}{c}\text { Panel B: First-stage regressions } \\
\text { Dependent variable is the first principal component of proximate factors }\end{array}$} \\
\hline State history & $\begin{array}{c}2.553^{* * *} \\
(3.70)\end{array}$ & $\begin{array}{c}3.077^{* * *} \\
(4.03)\end{array}$ & $\begin{array}{c}2.177 * * * \\
(2.81)\end{array}$ & $\begin{array}{c}2.197 * * * \\
(2.77)\end{array}$ & $\begin{array}{c}2.136^{* *} \\
(2.55)\end{array}$ \\
\hline $\begin{array}{l}\text { Agricultural } \\
\text { history }\end{array}$ & $\begin{array}{c}-0.202^{*} \\
(1.73)\end{array}$ & $\begin{array}{c}-0.216^{*} \\
(1.71)\end{array}$ & $\begin{array}{c}-0.212^{*} \\
(1.95)\end{array}$ & $\begin{array}{r}-0.181 \\
(1.60)\end{array}$ & $\begin{array}{r}-0.173 \\
(1.55)\end{array}$ \\
\hline $\begin{array}{l}\text { F-stat for } \\
\text { excluded } \\
\text { instruments (p) }\end{array}$ & $\begin{array}{c}8.03 \\
(0.001)\end{array}$ & $\begin{array}{c}8.43 \\
(0.001)\end{array}$ & $\begin{array}{c}4.24 \\
(0.020)\end{array}$ & $\begin{array}{c}4.00 \\
(0.024)\end{array}$ & $\begin{array}{c}3.43 \\
(0.040)\end{array}$ \\
\hline$R^{2}$ & 0.59 & 0.54 & 0.60 & 0.60 & 0.58 \\
\hline Observations & 72 & 72 & 72 & 72 & 68 \\
\hline \multicolumn{6}{|c|}{ Control variables included in first and second stage } \\
\hline $\begin{array}{l}\text { Baseline } \\
\text { controls }\end{array}$ & Yes & Yes & Yes & Yes & Yes \\
\hline $\begin{array}{l}\text { Controlling for } \\
\text { Colony origins }\end{array}$ & No & Yes & Yes & Yes & Yes \\
\hline $\begin{array}{l}\text { Controlling for } \\
\text { malaria } \\
\text { prevalence }\end{array}$ & No & No & Yes & Yes & Yes \\
\hline $\begin{array}{l}\text { Controlling for } \\
\text { protestant share }\end{array}$ & No & No & No & Yes & Yes \\
\hline $\begin{array}{l}\text { Excluding neo- } \\
\text { Europes }\end{array}$ & No & No & No & No & Yes \\
\hline
\end{tabular}

Notes:

1. *** indicates significance at the 1-percent level, ** at the 5-percent level, and * at the 10 -percent level.

2. Absolute values of heteroskasdastically robust t-statistics are in the parentheses. All regressions include an unreported constant.

3. Kleibergen and Paap under-identification test is a LM test of whether the equation is identified. Under the null hypothesis that the equation is under-identified, the matrix of reduced-form coefficients on the L1 excluded instruments has rank=K1-1 where K1=number of endogenous regressors. Under the null, the statistic is distributed as chi-squared with degrees of freedom=(L1-K1+1). A rejection of the null indicates that the matrix is full column rank; i.e., the model is identified (meaning the excluded variables are relevant).

4. The Sargan-Hansen test is a test of over-identifying restrictions. The joint null hypothesis is that the instruments are valid instruments, i.e., uncorrelated with the error term, and that the excluded instruments are correctly excluded from the estimated equation. Under the null, the test statistic is distributed as chi-squared in the number of (L-K) over-identifying restrictions. A rejection of the null suggests the instruments are invalid.

5. Baseline controls include absolute latitude, logged arable land area, and dummies for tropics, landlocked, island, Africa, Asia and Europe. FPC is the first principal component of the proximate factors.

6. Colony origins are dummies for the UK, France and Spain. Malaria prevalence is the index of malaria prevalence in 1966. Protestant share is fraction of population protestant in 1960. Neo-Europes are Australia, Canada, New Zealand and the US.

7. See Section 2 in text and Appendix A for discussions of the variables. 
Table 6: LIML Instrumental Variable Regressions and Further Robustness Checks

\begin{tabular}{|c|c|c|c|c|c|}
\hline \multicolumn{6}{|c|}{$\begin{array}{c}\text { Panel A: Second-stage regressions } \\
\text { Dependent variable is the standard deviation of annual output growth }\end{array}$} \\
\hline & $(1)$ & $(2)$ & (3) & $(4)$ & (5) \\
\hline $\begin{array}{l}\text { FPC of prox. } \\
\text { factors }\end{array}$ & $\begin{array}{c}-0.008^{*} \\
(1.76)\end{array}$ & $\begin{array}{c}-0.011 * * * \\
(2.81)\end{array}$ & $\begin{array}{c}-0.015^{* *} \\
(2.26) \\
\end{array}$ & $\begin{array}{c}-0.015^{* *} \\
(2.13) \\
\end{array}$ & $\begin{array}{c}-0.016^{*} \\
(1.94)\end{array}$ \\
\hline $\begin{array}{l}\text { Kleibergen and } \\
\text { Paap test (p) }\end{array}$ & 0.002 & 0.002 & 0.021 & 0.018 & 0.035 \\
\hline $\begin{array}{l}\text { Over- } \\
\text { identification } \\
\text { test (p) }\end{array}$ & 0.123 & 0.240 & 0.414 & 0.297 & 0.301 \\
\hline \multicolumn{6}{|c|}{$\begin{array}{c}\text { Panel B: First-stage regressions } \\
\text { Dependent variable is the first principal component of proximate factors }\end{array}$} \\
\hline State history & $\begin{array}{c}2.553 * * * \\
(3.70)\end{array}$ & $\begin{array}{c}3.077^{* * *} \\
(4.03)\end{array}$ & $\begin{array}{c}2.177^{* * *} \\
(2.81)\end{array}$ & $\begin{array}{c}2.197 * * * \\
(2.77) \\
\end{array}$ & $\begin{array}{c}2.136^{* *} \\
(2.55)\end{array}$ \\
\hline $\begin{array}{l}\text { Agricultural } \\
\text { history }\end{array}$ & $\begin{array}{c}-0.202^{*} \\
(1.73)\end{array}$ & $\begin{array}{c}-0.216^{*} \\
(1.71) \\
\end{array}$ & $\begin{array}{c}-0.212^{*} \\
(1.95) \\
\end{array}$ & $\begin{array}{r}-0.181 \\
(1.60)\end{array}$ & $\begin{array}{r}-0.173 \\
(1.55)\end{array}$ \\
\hline $\begin{array}{l}\text { F-stat for } \\
\text { excluded } \\
\text { instruments (p) }\end{array}$ & $\begin{array}{c}8.03 \\
(0.001)\end{array}$ & $\begin{array}{c}8.43 \\
(0.001)\end{array}$ & $\begin{array}{c}4.24 \\
(0.020)\end{array}$ & $\begin{array}{c}4.00 \\
(0.024)\end{array}$ & $\begin{array}{c}3.43 \\
(0.040)\end{array}$ \\
\hline$R^{2}$ & 0.52 & 0.54 & 0.60 & 0.60 & 0.58 \\
\hline Observations & 72 & 72 & 72 & 72 & 68 \\
\hline \multicolumn{6}{|c|}{ Control variables included in first and second stage } \\
\hline $\begin{array}{l}\text { Baseline } \\
\text { controls }\end{array}$ & Yes & Yes & Yes & Yes & Yes \\
\hline $\begin{array}{l}\text { Controlling for } \\
\text { Colony origins }\end{array}$ & No & Yes & Yes & Yes & Yes \\
\hline $\begin{array}{l}\text { Controlling for } \\
\text { malaria } \\
\text { prevalence }\end{array}$ & No & No & Yes & Yes & Yes \\
\hline $\begin{array}{l}\text { Controlling for } \\
\text { protestant share }\end{array}$ & No & No & No & Yes & Yes \\
\hline $\begin{array}{l}\text { Excluding neo- } \\
\text { Europes }\end{array}$ & No & No & No & No & Yes \\
\hline
\end{tabular}

Notes:

1. *** indicates significance at the 1-percent level, ** at the 5-percent level, and * at the 10-percent level.

2. Absolute values of heteroskasdastic robust t-statistics are in the parentheses. All regressions include an unreported constant.

3. Kleibergen and Paap under-identification test is a LM test of whether the equation is identified. Under the null hypothesis that the equation is under-identified, the matrix of reduced-form coefficients on the L1 excluded instruments has rank=K1-1 where K1=number of endogenous regressors. Under the null, the statistic is distributed as chi-squared with degrees of freedom=(L1-K1+1). A rejection of the null indicates that the matrix is full column rank; i.e., the model is identified (meaning the excluded variables are relevant).

4. The Sargan-Hansen test is a test of over-identifying restrictions. The joint null hypothesis is that the instruments are valid instruments, i.e., uncorrelated with the error term, and that the excluded instruments are correctly excluded from the estimated equation. Under the null, the test statistic is distributed as chi-squared in the number of $(\mathrm{L}-\mathrm{K})$ over-identifying restrictions. A rejection of the null suggests the instruments are invalid.

5. Baseline controls include absolute latitude, logged arable land area, and dummies for tropics, landlocked, island, Africa, Asia and Europe. FPC is the first principal component of the proximate factors.

6. Colony origins are dummies for the UK, France and Spain. Malaria prevalence is the index of malaria prevalence in 1966. Protestant share is fraction of population protestant in 1960. Neo-Europes are Australia, Canada, New Zealand and the US.

7. See Section 2 in text and Appendix A for discussions of the variables. 


\section{$\underline{\text { References }}$}

Acemoglu, Daron, Isaias Chaves, Philip Osafo-Kwaako and James Robinson, "Indirect rule and state weakness in Africa: Sierra Leone in comparative perspective,” working paper (2013).

Acemoglu, Daron, Francisco Gallego and James Robinson, "Institutions, Human Capital and Development,” National Bureau of Economic Research Working Paper 19933 (2014).

Acemoglu, Daron, Simon Johnson, and James Robinson, “The Colonial Origins of Comparative Development: An Empirical Investigation,” American Economic Review, 91 (2001), 1369-1401.

Acemoglu, Daron, Simon Johnson, and James Robinson, "Reversal of Fortune: Geography and Institutions in the Making of the Modern World Income Distribution,” Quarterly Journal of Economics, 117:4 (2002), 1231-1294.

Acemoglu, Daron., Simon Johnson, James Robinson, and Yunyong Thaicharoen, “Institutional causes, Macroeconomic Symptoms: Volatility, Crises and Growth,” Journal of Monetary Economics, 50 (2003), 49-123.

Ang, James B., “Institutions and the Long-Run Impact of Early Development,” Journal of Development Economics, 105 (2013), 1-18.

Angrist, Joshua D. and Jörn-Steffen Pischke, Mostly Harmless Econometrics: An Empiricist's Companion (Princeton: Princeton University Press, 2008).

Ashraf, Quamrul and Oded Galor, “The “Out of Africa” Hypothesis, Human Genetic Diversity, and Comparative Economic Development,” American Economic Review, 103:1 (2013), 1-46.

Bai, Jushan and Pierre Perron, "Estimating and Testing Linear Models with Multiple Structural Changes,” Econometrica, 66:1 (1998), 47-78.

Bai, Jushan, and Pierre Perron, “Computation and Analysis of Multiple Structural Change Models,” Journal of Applied Econometrics, 18 (January/February 2003), 1-22.

Barro, Robert, “Determinants of Democracy,” Journal of Political Economy, Pt. 2, 107:6 (1999), S158-183.

Bockstette, Valerie, Areendam Chanda, and Louis Putterman, "States and Markets: The Advantage of an Early Start,” Journal of Economic Growth, 7 (2002), 347-369.

Clots-Figueras Irma, and Paolo Masella, “Education, Language and Identity,” Economic Journal, 123 (August 2013), F332-F357. 
Comin, Diego, William Easterly, and Erick Gong, "Was the Wealth of Nations Determined in 1000 BC?” American Economic Journal: Macroeconomics, 2:3 (2010), 65-97.

Cuberes, David and Michal Jerzmanowski, “Democracy, Diversification and Growth Reversals,” Economic Journal, 119 (October 2009), 1270-1302.

Diamond, Jared, Guns, Germs, and Steel: The Fates of Human Societies (New York and London: Norton, 1997).

Easterly, William, and Ross Levine, “Africa’s Growth Tragedy: Policies and Ethnic Divisions,” Quarterly Journal of Economics, 112 (1997), 1203-1246.

Easterly, William, and Ross Levine, “Tropics, Germs and Crops: How Endowments Influence Economic Development," Journal of Monetary Economics, 50 (2003), 3-39. Easterly, William, and Ross Levine, “The European Origins of Economic Development,” National Bureau of Economic Research Working Paper 18162 (2012).

Engerman, Stanley L., and Kenneth L. Sokoloff, “Factor Endowments, Institutions, and Differential Paths of Growth Among New World Economies: A View from Economic Historians of the United States” (pp. 260-304) in Stephen Harber (ed.), How Latin America Fell Behind (Stanford: Stanford University Press, 1997).

Engerman, Stanley L., and Kenneth L. Sokoloff, Economic Development in the Americans since 1500: Endowments and Institutions (Cambridge: Cambridge University Press, 2012).

Fatás, Antonio, and Ilian Mihov, “The Case for Restricting Fiscal Policy Discretion,” Quarterly Journal of Economics, 118:4 (2003), 1419-1447.

Ferreira da Silva, Gisele, “The Impact of Financial System Development on Business Cycles Volatility: Cross-Country Evidence,” Journal of Macroeconomics, 24:2 (2002), 233253.

Fearon, James D., "Ethnic and Cultural Diversity by Country,” Journal of Economic Growth, 8 (2003), 195-222.

Fors, Heather, “Do Island States Have Better Institutions?” Journal of Comparative Economics, 42:1 (2014), 34-60.

Fowler, James and Darren Schreiber, "Biology, Politics, and the Emerging Science of Human Nature,” Science, 322 (2008), 912-914.

Gallop John L., Andrew Mellinger, and Jeffrey D. Sachs, Geography Datasets, (http://www2.cid.harvard.edu/ciddata/geographydata.htm: Center for International Development at Harvard University (CID), 2001). 
Galor, Oded, and David N. Weil, "Population, Technology and Growth: From Malthusian Stagnation to the Demographic Transition and Beyond," American Economic Review, 90:4 (2000), 806-828.

Galor, Oded, Omer Moav, and Dietrich Vollrath, "Inequality in Landownership, the Emergence of Human-Capital Promoting Institutions, and the Great Divergence,” Review of Economic Studies, 76:1 (2009), 143-179.

Glaeser, Edward L., Rafael La Porta, Florencio Lopez-de-Silanes, and Andrei Shleifer, “Do Institutions Cause Growth?” Journal of Economic Growth, 9:3 (2004), 271-303.

Hibbs, Douglas A., Jr., and Ola Olsson, "Geography, Biogeography, and Why Some Countries are Rich and Others are Poor," Proceedings of the National Academy of Sciences of the United States of America, 101:10 (2004), 3715-3720.

Jones, Benjamin F., and Benjamin A. Olken, “The Anatomy of Start-Stop Growth,” Review of Economics and Statistics, 90:3 (August 2008), 582-587.

Klomp, Jeroen, and Jakob de Hann, "Political Institutions and Economic Volatility,” European Journal of Political Economy, 25 (2009), 311-326.

Knack, Stephen, and Philip Keefer, "Does Social Capital Have a Economic Payoff: A CrossCountry Investigation,” Quarterly Journal of Economics, 112:4 (1997), 1251-1288.

Koren Miklós and Silvana Tenreyro, “Volatility and Development,” Quarterly Journal of Economics, 122:1 (2007), 243-287.

La Porta, Rafael, Florencio Lopez-de-Silanes, Andrei Shleifer, and Robert Vishny, “Legal Determinants of External Finance,” Journal of Finance, 52 (1997), 1131-1150.

Lensink, Robert, and Oliver Morrissey, “Foreign Direct Investment: Flows, Volatility, and the Impact on Growth,” Review of International Economics, 14:3 (2006), 478-493.

Lucas, Robert E., Jr., “On the Mechanics of Economic Development,” Journal of Monetary Economics, 22:1 (1988), 3-42.

Malik, Adeel, and Jonathan R. W. Temple, “The Geography of Output Volatility,” Journal of Development Economics, 90:2 (2009), 163-178.

Marshall, Monty, Ted Robert Gurr, and Keith Jaggars, Polity IV Project: Political Regime Characteristics and Transitions 1800-2012, (www.systemicpeace.org: Center for Systemic Peace, 2013).

Mobarak, Ahmed Mushfiq, “Democracy, Volatility, and Economic Development,” Review of Economics and Statistics, 87:2 (May 2005), 348-361.

Nunn, Nathan, “The importance of history for economic development,” National Bureau of Economic Research Working Paper 14899 (2009). 
Olsson, Ola, and Douglas A. Hibbs, Jr., "Biogeography and Long-Run Economic Development,” European Economic Review, 49:4 (2005), 909-938.

Parker, Philip M., National Cultures of the World: A Statistical Reference, Cross-Cultural Statistical Encyclopedia of the World, (Westport, CT: Greenwood Press, 1997).

Peregrine, Peter N., “Atlas of Cultural Evolution,” World Cultures, 14:1 (2003), 1-75.

Pritchett, Lant, "Understanding Patterns of Economic Growth: Searching for Hills among Plateaus, Mountains, and Plains,” World Bank Economic Review, 14:2 (2000), 221-250.

Putterman, Louis, "State Antiquity Index Version 3," (http://www.econ.brown.edu/fac/Louis.Putterman, 2004).

Putterman, Louis, with Cary Anne Trainor, “Agricultural Transition Year Country Data Set,” (http://www.econ.brown.edu/fac/Louis.Putterman, 2006).

Putterman, Louis, and David Weil, "Post-1500 Population Flows and the Long-Run Determinants of Economic Growth and Inequality,” Quarterly Journal of Economics, 125:4 (2010), 1627-1682.

Raddatz, Claudio, "Liquidity Needs and Vulnerability to Financial Underdevelopment," Journal of Financial Economics, 80 (2006), 672-722.

Rodrik, Dani, "Where Did All the Growth Go? External Shocks, Social Conflict, and Growth Collapses,” Journal of Economic Growth, 4:4 (1999), 385-412.

Rodrik, Dani, “Institutions for High-Quality Growth: What They Are and How to Acquire Them,” Studies in Comparative International Development, 35:3 (2000), 3-31.

Spolaore, Enrico, and Romain Wacziarg, “The Diffusion of Development,” Quarterly Journal of Economics, 124:2 (2009), 469-529.

Spolaore, Enrico, and Romain Wacziarg, "How Deep Are the Roots of Economic Development,” Journal of Economic Literature, 51:2 (2013), 325-369.

Stock, J. H., J. H. Wright, and M. Yogo, “A Survey of Weak Instruments and Weak Identification in Generalized Method of Moments,” Journal of Business and Economic Statistics, 20 (2002), 518-529.

Temple, Jonathan R. W., “Initial Condition, Social Capital and Growth in Africa,” Journal of African Economics, 7:3 (1998), 309-347. 


\section{Appendix}

The appendix is organized as follows:

- Appendix A provides more details on data definitions and sources.

- Appendix B provides the results of further robustness checks.

- Appendix C provides the baseline results when historical variables are unadjusted for population migration since 1500 C.E.

- Appendix D provides the supplementary results behind the principal component analysis relating to historical variables and covariates of output volatility.

- Appendix E provides a list of countries included in the study. 


\section{Appendix A: Data}

- Absolute latitude: absolute value of the latitude of the country (THE WORLD FACTBOOK, CIA).

- Arable land area: log of total arable land area in sq. km (THE WORLD FACTBOOK, CIA).

- Climate and soil: climate includes five measures of temperatures (average, minimum monthly high, maximum monthly high, minimum monthly low, and maximum monthly low, all in centigrade), and four measures of humidity (morning minimum, morning maximum, afternoon minimum and afternoon maximum, all in percent). Soil includes seven types of soil qualities (steppe [low latitude], desert [low latitude], steppe [middle latitude], desert [middle latitude], dry steppe wasteland, desert dry winter, and highland). (Parker, 1997).

- Colonial origins: are four dummy variables representing former colonies of the UK, France, Spain or others. It takes on the value of one if the country is a former colony of one of the above-mentioned countries, zero otherwise. (THE WORLD FACTBOOK, CIA).

- Democracy institutions: is the variable Polity2 that is calculated by subtracting the autocratic score from the democratic score for each country. If a country has a "standardized authority score” (66, 77 or 88) for a particular year, it will be converted to “conventional polity scores”. This variable has a range from -10 to 10, with 10 being the perfect score for democracy (POLITY IV PROJECT, Marshall, Gurr, and Jaggers, 2013).

- Discretionary fiscal policy: measures the changes in fiscal policy that are exogenous to changes in economic conditions. Following the approach of Fatás and Mihov (2013), we run the regression, $\Delta G_{i, t}=\alpha_{i}+\beta_{i} \Delta Y_{i, t}+\delta_{i} W_{i, t}+\in_{i, t}$ for each country, where $\Delta G_{i, t}$ is the change in government spending for country $i$ at time $t, \Delta Y_{i, t}$ is the growth of per capita GDP, and $W_{i, t}$ is the vector of control variables. To avoid endogeneity of output, $\Delta Y_{i, t}$ is 
instrumented by two lags of $\Delta Y_{i, t}$, logarithm of oil price, lagged inflation and the lagged value of government spending growth. The control variables include inflation, inflation squared and a time trend. The country-specific discretionary fiscal policy is measured by the standard deviation of the residual, $\in_{i, t}$. We restrict our sample to countries with at least 20 years of complete data (GDP is real GDP in constant local currency units from World Development Indicators. Government spending is general government final consumption expenditure in constant local currency units from World Development Indicators. Price level is GDP deflator from World Development Indicators. Index of oil price is the logarithm of petroleum spot price in US dollars per barrel from International Financial Statistics).

- Ethnic fractionalization: is the probability that two individuals selected at random from a country will be from different ethnic groups (Fearon, 2003).

- European share of population: is the share of the year 2000 population in every country that is descended from people in Belgium, France, Germany, Italy, the Netherlands, Portugal, Spain and the United Kingdom in the year 1500CE (Constructed using Putterman and Weil’s (2010) World Migration Matrix).

- Financial development: is the average annual ratio of credits provided by financial intermediaries (banks and non-banks) to the private sector to GDP, in percentage terms. (Domestic credits provided by the banking sector, \% of GDP, World Development Indicators).

- Foreign direct investment: FDI to GDP is the average annual ratio of inward foreign direct investment to GDP, in percentage (Foreign direct investment, net inflow, \% of GDP, World Development Indicators).

- Income level: is the log of Purchasing Power Parity adjusted per capita GDP in 2002 (rgdpch, Penn World Tables, version 6.3). 
- Island: is a dummy variable taking on the value of one if a country is an island, zero otherwise (THE WORLD FACTBOOK, CIA).

- Malaria prevalence: is the index of malaria prevalence in 1966 (Gallop et al., 200).

- Neo-Europes: is a dummy variable taking on the value of one if a country is Australia, Canada, New Zealand or the US, zero otherwise.

- Political stability: is the Political Risk Index from International Country Risk Guide for the year 2000, which is an index between zero and one, with one being perfectly politically stable.

- Protestant share: is the fraction of population protestant in 1960 (Barro, 1999)

- Tropics: a dummy variable taking on the value of one if the country is tropical and zero otherwise (Comin, Easterly and Gong, 2010). 


\section{Appendix B: Robustness Checks}

All of the regressions in the baseline regressions include the geographic variables of absolute latitude, tropical region, arable land area, landlocked, island, and the continent dummies of Africa, Asia and Europe. Given all these controls, we still find the history of state-level political institutions affecting both measures of macroeconomic volatility significantly. In this section, we further investigate the robustness of the main result by using alternative subsamples or by adding more control variables to the baseline regression.

\section{[Insert Table B.1 about here]}

Table B.1 reports the regression results of robustness checks. As can be seen from Figure 1, many African countries experience both high output volatility and relatively short history of state-level political institutions. We are then concerned that the estimated effect of state history is mainly caused by the difference between African countries and the rest of the world. Having included the dummy variable for Africa in the baseline regressions mitigates but not eliminates the concern. We thus exclude the African countries from the sample and report the regression results in Column 1, Table B.1: the estimated effect of state history on output volatility increases from -0.049 to -0.067 and remains statistically significant at the one percent level in Panel A. In Panel B, the estimated marginal effect of state history on the occurrence of trend-growth breaks also increases from -0.559 to -0.665 and remains statistically significant at the 10 percent level. Moreover, the goodness-of-fit improves in both regressions $\left(R^{2}=0.25\right)$. We can now be confident that the estimated effect of state history on macroeconomic volatility is not due to the inclusion of African countries in the sample.

The next concern is the extent of controls for geography. In the baseline regressions, we include absolute latitude and a tropical dummy to capture the potential effects of climates and soils on macroeconomic volatility and state history. Now, we ask whether a more 
detailed classification of climates and soils can better capture their effects. Column 2, Table B.1, reports the regression results when we include four temperature, four humidity and seven soil zones from Parker (1997) in the baseline regressions: the results in Panel A show that the magnitude of the state history estimate is reduced to -0.037 from the baseline result of -0.049 , but remains statistically significant at the 5 percent level. The F-test for the joint effect of the 15 additional climate and soil variables gives a P-value of 0.81 , indicating that they are not jointly significant in explaining output volatility. In Panel B, the t-statistic of the estimated marginal effect of state history increases from 1.82 in the baseline result to 2.12 after the additional climate and soil variables are included in the regression. Again, the joint estimated effect of the additional climate and soil variables is not statistically significant $(\mathrm{P}$-value $=$ 0.24). In short, the estimated effects of state history on both output volatility and the occurrence of trend-growth breaks remain robust after including the 15 additional controls for climates and soils.

The role of human capital in long-run development has been emphasized by a number of researchers such as Galor and Weil (2000), Glaeser et al. (2004), and Galor, Moav and Vollrath (2009). Easterly and Levine (2012) show that the share of the European population in colonial times has a large and significant impact on income per capita today. They argue that European colonizers brought with them social values, ideologies and norms in addition to general education, scientific and technological knowledge, knowledge of access to international markets, and the human capital needed in building quality institutions. As such, the share of the European population can be an important factor not only for long-run growth but also for macroeconomic volatility. Using Putterman and Weil’s (2010) World Migration Matrix, we construct a variable 'European’ which is the share of the year 2000 population in every country that is descended from people in Belgium, France, Germany, Italy, the Netherlands, Portugal, Spain and the United Kingdom in the year 1500 C.E. Following 
Spolaore and Wacziarg (2013), we restrict our attention to a sample of countries with fewer than 30 percent of Europeans.

Column 3 of Panel A, Table B.1, shows that the estimated effect of 'European' on output volatility is negative and statistically significant at the 10 percent level. Because the history of state-level political institutions has already been adjusted for population migration since 1500 C.E., the European variable represents the effects of European ancestry on output volatility over and above what has already been explained by the state history of European ancestry. The estimate indicates that countries with a larger share of current population descended from Europe experience less output volatility. More importantly, the estimate for state history remains unchanged from the baseline result and statistically significant at the 5 percent level even given the presence of 'European' in the regression.

Column 3 of Panel B, Table B.1, shows that the estimated effect of 'European' on the occurrence of trend-growth breaks is negative, but statistically insignificant at conventional levels. In contrast, the estimated marginal effect of state history is -0.587 and is statistically significant at the 5 percent level. Hence, even though European is important for output volatility, it does not undermine the strength of the linkage between state history and macroeconomic volatility.

Rodrik (1999) shows that divided societies and weak institutions of conflict management amplify external shocks, causing volatile growth and crises. He adopts income inequality and ethnolinguistic fragmentation as indicators of divided societies. Similar to his approach, we use the variable 'ethnic fractionalization', which is defined as the probability that two individuals selected at random from a country will be from different ethnic groups (Fearon, 2003). It is expected that greater ethnic fractionalization is associated with more divided countries, which hinders the ability of the authorities to manage external shocks. 
Column 4, Table B.1, shows the results when ethnic fractionalization is added to the baseline regressions. In Panel A, the estimated effect of ethnic fractionalization on output volatility is positive and statistically significant at the 10 percent level $(0.019$, t-statistic $=$ 1.76). Greater ethnic fractionalization is thus associated with greater output volatility, which is consistent with our expectation. On the contrary, the estimated marginal effect of ethnic fractionalization on the occurrence of trend-growth breaks is negative and statistically significant at the 5 percent level $(-0.573$, t-statistic $=2.29)$ in Panel $\mathrm{B}$, indicating that greater ethnic fractionalization is associated with a smaller chance of trend-growth breaks. Hence, the results for ethnic fractionalization are mixed as it increases the high-frequency output volatility, but reduces the occurrence of medium-run trend-growth breaks. ${ }^{18}$ However, the estimates of state history, which remain to be negative and statistically significant, are robust to the addition of ethnic fractionalization in both panels.

Column 5, Table B.1, checks the sensitive of the state history estimate when democracy is added to the baseline regressions. Previous studies find that democratic countries are less volatile (Rodrik, 2000; Mobarak, 2005, Cuberes and Jerzmanowski, 2009). Using Polity2 from the POLITY IV PROJECT (Marshall, Gurr and Jaggers, 2013) to measure democracy, we confirm the finding of previous studies that democracy has a significant stabilizing effect on both high-frequency output volatility $(-0.002$, t-statistic $=5.89)$ and medium-run trend-growth breaks $(-0.023$, t-statistic $=1.64)$. More importantly, the magnitudes and statistical significances of the state history estimates in Column 5 of Panel A and $\mathrm{B}$ are roughly the same as their baseline results after controlling for the effect of

\footnotetext{
${ }^{18}$ We regard this result of ethnic fractionalization in reducing medium-run trend-growth volatility interesting, and it may highlight the potential dual roles of ethnic diversity on macroeconomic volatility. On the one hand, ethnic fractionalization increases social divides and conflicts, but, on the other, it may increase ideas and innovations. Ashraf and Galor (2013) demonstrate that human genetic diversity has a hump-shaped effect on the logged population density in 1500 C.E.
} 
democracy. Hence, the evidence suggests that state history and democracy both affect macroeconomic volatility significantly, but their effects are largely independent of each other.

A stylized fact in the macroeconomic volatility literature is that less developed countries are more volatile than developed ones (Lucas, 1988). Koren and Tenreyro (2007) show that as countries develop, they move their productive structure from more volatile to less volatile sectors. Therefore, if state history reduces macroeconomic volatility of a country primarily through enhancing its growth and development, then controlling for the stages of development in the regression should render the estimate for state history insignificant, but the estimate for development significant. If, however, state history operates primarily through routes other than development to affect macroeconomic volatility, the baseline estimate for state history should be unaffected by controlling for the stages of development. Of course, state history can affect macroeconomic volatility through both routes, and in which case the magnitude of the state history estimate should be reduced but remain statistically significant.

Column 6, Table B.1, reports the results when log income per capita in 2002 is added to the baseline regressions to control for the stages of development. Results in Panel A show that the estimate of state history is substantially smaller in both magnitude and statistical significance $(-0.027$, t-statistic $=1.88)$ than the baseline result after controlling for development. However, it is still statistically significant at the 10 percent level in explaining output volatility. Moreover, the estimate for log income per capita in 2002 is highly significant $(-0.011$, t-statistic $=2.85)$. Taken together, these results appear to suggest that state history reduces output volatility of a country by both enhancing the country's development as well as by operating independently through other routes.

Results in Column 6 of Panel B, Table B.1, indicate that controlling for development leaves the state history estimate unchanged from the baseline result in the regression of the 
occurrence of trend-growth breaks. The estimate for log income per capita in 2002, however, is non-significant. Hence, the evidence suggests that the stages of development appear to be important for high-frequency output volatility, but not so for the occurrence of medium-run trend-growth breaks.

This section attempts to check how sensitive is the baseline estimate of state history to the additional controls of structural variables which are well-known to be related to macroeconomic volatility. It is reassuring to find that the baseline estimate of state history is largely unaffected by the inclusion of these addition controls. Furthermore, we confirm findings of previous studies that the share of European population, ethnic fractionalization, democratic institutions, and development all play a role in affecting macroeconomic volatility today. 
Table B.1: Robustness Checks

\begin{tabular}{|c|c|c|c|c|c|c|}
\hline & $\begin{array}{c}\text { Excluding } \\
\text { Africa } \\
\text { (1) }\end{array}$ & $\begin{array}{l}\text { Controlling } \\
\text { for climate } \\
\text { and soil } \\
\text { (2) }\end{array}$ & $\begin{array}{l}\text { Controlling } \\
\text { for } \\
\text { European } \\
(3)\end{array}$ & $\begin{array}{l}\text { Controlling } \\
\text { for } \\
\text { ethnicity } \\
(4)\end{array}$ & $\begin{array}{l}\text { Controlling } \\
\text { for } \\
\text { democracy } \\
(5)\end{array}$ & $\begin{array}{l}\text { Controlling } \\
\text { for } \\
\text { income } \\
(6)\end{array}$ \\
\hline \multicolumn{7}{|c|}{ Panel A: Dependent variable is the standard deviation of annual output growth (OLS regressions) } \\
\hline State history & $\begin{array}{c}-0.067 * * * \\
(3.54)\end{array}$ & $\begin{array}{c}-0.037 * * \\
(2.07)\end{array}$ & $\begin{array}{c}-0.043 * * \\
(2.38)\end{array}$ & $\begin{array}{c}-0.044 * * * \\
(2.74)\end{array}$ & $\begin{array}{c}-0.055^{* * * *} \\
(3.39)\end{array}$ & $\begin{array}{c}-0.027^{*} \\
(1.88)\end{array}$ \\
\hline $\begin{array}{l}\text { P-value for } \\
\text { climate \& soil }\end{array}$ & & [0.81] & & & & \\
\hline $\begin{array}{l}\text { European share } \\
\text { of population }\end{array}$ & & & $\begin{array}{l}-0.073^{*} \\
(1.93)\end{array}$ & & & \\
\hline $\begin{array}{l}\text { Ethnic } \\
\text { fractionalization }\end{array}$ & & & & $\begin{array}{l}0.019 * \\
(1.79)\end{array}$ & & \\
\hline $\begin{array}{l}\text { Democratic } \\
\text { institutions }\end{array}$ & & & & & $\begin{array}{c}-0.002 * * * \\
(5.89)\end{array}$ & \\
\hline $\begin{array}{l}\text { Log income in } \\
2002\end{array}$ & & & & & & $\begin{array}{c}-0.011 * * * \\
(2.85)\end{array}$ \\
\hline $\begin{array}{l}\text { Baseline } \\
\text { controls }\end{array}$ & Yes & Yes & Yes & Yes & Yes & Yes \\
\hline Observations & 80 & 117 & 89 & 116 & 116 & 111 \\
\hline$R^{2}$ & 0.25 & 0.36 & 0.15 & 0.19 & 0.29 & 0.26 \\
\hline \multicolumn{7}{|c|}{$\begin{array}{c}\text { Panel B: Dependent variable is a dummy variable indicating the presence of trend-growth breaks } \\
\text { (Probit regressions) }\end{array}$} \\
\hline State history & $\begin{array}{c}-0.665^{*} \\
(1.72)\end{array}$ & $\begin{array}{c}-0.582^{* *} \\
(2.12)\end{array}$ & $\begin{array}{c}-0.587 * * \\
(2.02)\end{array}$ & $\begin{array}{c}-0.710 * * \\
(2.34)\end{array}$ & $\begin{array}{c}-0.632 * * \\
(2.05)\end{array}$ & $\begin{array}{c}-0.578^{*} \\
(1.81)\end{array}$ \\
\hline $\begin{array}{l}\text { P-value for } \\
\text { climate \& soil }\end{array}$ & & {$[0.24]$} & & & & \\
\hline $\begin{array}{l}\text { European share } \\
\text { of population }\end{array}$ & & & $\begin{array}{l}-0.128 \\
(0.17)\end{array}$ & & & \\
\hline $\begin{array}{l}\text { Ethnic } \\
\text { fractionalization }\end{array}$ & & & & $\begin{array}{c}-0.573^{* *} \\
(2.29)\end{array}$ & & \\
\hline $\begin{array}{l}\text { Democratic } \\
\text { institutions }\end{array}$ & & & & & $\begin{array}{c}-0.023^{*} \\
(1.64)\end{array}$ & \\
\hline $\begin{array}{l}\text { Log income in } \\
2002\end{array}$ & & & & & & $\begin{array}{l}0.076 \\
(1.02)\end{array}$ \\
\hline $\begin{array}{l}\text { Baseline } \\
\text { controls }\end{array}$ & Yes & Yes & Yes & Yes & Yes & Yes \\
\hline Observations & 61 & 89 & 67 & 93 & 94 & 93 \\
\hline Pseudo $R^{2}$ & 0.25 & 0.23 & 0.19 & 0.17 & 0.15 & 0.13 \\
\hline
\end{tabular}

Notes:

1. $\quad * * *$ indicates significance at the 1-percent level, ** at the 5-percent level, and * at the 10-percent level.

2. Absolute values of heteroskasdastically robust t-statistics are in the parentheses.

3. All regressions include an unreported constant.

4. Baseline controls include absolute latitude, logged arable land area, and dummies for tropics, landlocked, island, Africa, Asia and Europe.

5. See Section 2 in text and Appendix A for discussions of the variables. 
Appendix C: Baseline Results (Without Adjusting for Population Migration)

\begin{tabular}{|c|c|c|c|c|c|c|}
\hline \multicolumn{7}{|c|}{ Dependent variable is the standard deviation of annual output growth (1960-2011) } \\
\hline \multicolumn{7}{|c|}{ Panel A } \\
\hline & 1 & 2 & 3 & 4 & 5 & 6 \\
\hline State history & $\begin{array}{c}-0.036 * * * \\
(2.63)\end{array}$ & & & & & \\
\hline Agri. history & & $\begin{array}{c}8.79 \mathrm{e}-07 \\
(0.58)\end{array}$ & & & & \\
\hline $\begin{array}{l}\text { Technology } \\
\text { 1000BC }\end{array}$ & & & $\begin{array}{l}0.011 \\
(1.40)\end{array}$ & & & \\
\hline $\begin{array}{l}\text { Technology } \\
\text { 1CE }\end{array}$ & & & & $\begin{array}{l}-0.007 \\
(0.93)\end{array}$ & & \\
\hline $\begin{array}{l}\text { Technology } \\
\text { 1500CE }\end{array}$ & & & & & $\begin{array}{l}-0.010 \\
(0.53)\end{array}$ & \\
\hline $\begin{array}{l}\text { Genetic } \\
\text { distance }\end{array}$ & & & & & & $\begin{array}{c}-1.06 e-07 \\
(0.02)\end{array}$ \\
\hline $\begin{array}{l}\text { Absolute } \\
\text { latitude }\end{array}$ & $\begin{array}{l}0.000 \\
(0.99)\end{array}$ & $\begin{array}{l}0.000 \\
(1.09)\end{array}$ & $\begin{array}{l}0.000 \\
(0.60)\end{array}$ & $\begin{array}{l}0.001^{*} \\
(1.69)\end{array}$ & $\begin{array}{c}-4.98 \mathrm{e}-06 \\
(0.01)\end{array}$ & $\begin{array}{c}0.000 \\
(0.81)\end{array}$ \\
\hline Tropics & $\begin{array}{l}0.008 \\
(0.93)\end{array}$ & $\begin{array}{l}0.009 \\
(1.23)\end{array}$ & $\begin{array}{l}0.008 \\
(0.83)\end{array}$ & $\begin{array}{l}0.004 \\
(0.43)\end{array}$ & $\begin{array}{l}-0.003 \\
(0.32)\end{array}$ & $\begin{array}{l}0.002 \\
(0.20)\end{array}$ \\
\hline $\begin{array}{l}\text { Log of } \\
\text { arable land }\end{array}$ & $\begin{array}{l}-0.001 \\
(0.67) \\
\end{array}$ & $\begin{array}{l}-0.002 \\
(1.35) \\
\end{array}$ & $\begin{array}{l}-0.001 \\
(0.69) \\
\end{array}$ & $\begin{array}{c}-0.003^{* *} \\
(2.13) \\
\end{array}$ & $\begin{array}{l}-0.002 \\
(1.23) \\
\end{array}$ & $\begin{array}{c}-0.004 * * \\
(2.51) \\
\end{array}$ \\
\hline Landlocked & $\begin{array}{l}0.002 \\
(0.24)\end{array}$ & $\begin{array}{l}0.003 \\
(0.42)\end{array}$ & $\begin{array}{l}0.005 \\
(0.77)\end{array}$ & $\begin{array}{l}-0.007 \\
(1.00)\end{array}$ & $\begin{array}{l}-0.010 \\
(1.41)\end{array}$ & $\begin{array}{l}-0.005 \\
(0.74)\end{array}$ \\
\hline Island & $\begin{array}{c}-0.013^{* *} \\
(2.40)\end{array}$ & $\begin{array}{l}-0.008 \\
(1.42)\end{array}$ & $\begin{array}{l}-0.004 \\
(0.53)\end{array}$ & $\begin{array}{c}-0.016^{* * *} \\
(2.86)\end{array}$ & $\begin{array}{c}-0.013^{* *} \\
(2.14) \\
\end{array}$ & $\begin{array}{c}-0.017 * * * \\
(3.21)\end{array}$ \\
\hline Africa & $\begin{array}{c}0.015^{* *} \\
(2.48)\end{array}$ & $\begin{array}{c}0.013^{* *} \\
(2.23)\end{array}$ & $\begin{array}{l}0.010^{*} \\
(1.68)\end{array}$ & $\begin{array}{c}0.019 * * \\
(2.60)\end{array}$ & $\begin{array}{c}0.020^{* *} \\
(2.59)\end{array}$ & $\begin{array}{c}0.016^{* * *} \\
(2.73)\end{array}$ \\
\hline Asia & $\begin{array}{c}0.023 * * * \\
(2.87)\end{array}$ & $\begin{array}{l}0.007 \\
(0.94)\end{array}$ & $\begin{array}{l}0.004 \\
(0.59)\end{array}$ & $\begin{array}{c}0.023^{* * *} \\
(2.83)\end{array}$ & $\begin{array}{c}0.018^{* *} \\
(2.05)\end{array}$ & $\begin{array}{c}0.020 * * * \\
(2.75)\end{array}$ \\
\hline Europe & $\begin{array}{l}0.010 \\
(1.01)\end{array}$ & $\begin{array}{l}-0.004 \\
(0.37)\end{array}$ & $\begin{array}{l}-0.005 \\
(0.53)\end{array}$ & $\begin{array}{l}-0.005 \\
(0.47)\end{array}$ & $\begin{array}{l}0.003 \\
(0.20)\end{array}$ & $\begin{array}{c}-0.002 \\
(0.16)\end{array}$ \\
\hline Observations & 113 & 113 & 103 & 123 & 111 & 128 \\
\hline$R^{2}$ & 0.15 & 0.09 & 0.08 & 0.14 & 0.11 & 0.13 \\
\hline \multicolumn{7}{|c|}{ Panel B } \\
\hline & $\begin{array}{c}\text { Agri. } \\
\text { history }\end{array}$ & $\begin{array}{c}\text { Technology } \\
\text { 1000BC }\end{array}$ & $\begin{array}{c}\text { Technology } \\
\text { 1CE }\end{array}$ & $\begin{array}{c}\text { Technology } \\
\text { 1500CE }\end{array}$ & $\begin{array}{l}\text { Genetic } \\
\text { distance }\end{array}$ & $\begin{array}{l}\text { FPC of } \\
\text { history }\end{array}$ \\
\hline State history & $\begin{array}{c}-0.042^{* * * *} \\
(2.93)\end{array}$ & $\begin{array}{c}-0.043 * * * \\
(3.12)\end{array}$ & $\begin{array}{c}-0.030 * * \\
(2.18)\end{array}$ & $\begin{array}{c}-0.029 * \\
(1.90)\end{array}$ & $\begin{array}{c}-0.041^{* *} \\
(2.36)\end{array}$ & \\
\hline $\begin{array}{l}\text { Column } \\
\text { variable }\end{array}$ & $\begin{array}{c}2.79 \mathrm{e}-06^{*} \\
(1.79)\end{array}$ & $\begin{array}{c}0.018 * * \\
(2.48)\end{array}$ & $\begin{array}{l}-0.005 \\
(0.68)\end{array}$ & $\begin{array}{l}0.007 \\
(0.53)\end{array}$ & $\begin{array}{c}-5.68 \mathrm{e}-06 \\
(0.72)\end{array}$ & $\begin{array}{l}-0.001 \\
(0.43)\end{array}$ \\
\hline $\begin{array}{l}\text { Baseline } \\
\text { controls }\end{array}$ & Yes & Yes & Yes & Yes & Yes & Yes \\
\hline Observations & 113 & 95 & 109 & 99 & 111 & 84 \\
\hline$R^{2}$ & 0.17 & 0.22 & 0.17 & 0.17 & 0.17 & 0.14 \\
\hline
\end{tabular}

Notes:

1. $\quad * * *$ indicates significance at the 1-percent level, ** at the 5-percent level, and * at the 10-percent level.

2. Absolute values of heteroskasdastically robust t-statistics are in the parentheses. All regressions include an unreported constant.

3. Baseline controls include absolute latitude, logged arable land area, and dummies for tropics, landlocked, island, Africa, Asia and Europe. FPC is the first principal component of historical variables.

4. See Section 2 in text and Data Appendix for discussions of the variables. 


\section{Appendix D}

Table D.1: Correlation Coefficients of Historical Variables

\begin{tabular}{|c|c|c|c|c|c|c|}
\hline & $\begin{array}{l}\text { State } \\
\text { history }\end{array}$ & $\begin{array}{l}\text { Agricultural } \\
\text { history }\end{array}$ & $\begin{array}{l}\text { Technology } \\
\text { at } 1,000 \mathrm{BC}\end{array}$ & $\begin{array}{l}\text { Technology } \\
\text { at } 1 \mathrm{CE}\end{array}$ & $\begin{array}{l}\text { Technology } \\
\text { at } 1,500 \mathrm{CE}\end{array}$ & $\begin{array}{l}\text { Genetic } \\
\text { distance }\end{array}$ \\
\hline $\begin{array}{l}\text { State } \\
\text { history }\end{array}$ & 1.00 & & & & & \\
\hline $\begin{array}{l}\text { Agricultural } \\
\text { history }\end{array}$ & $0.68^{* * *}$ & 1.00 & & & & \\
\hline $\begin{array}{l}\text { Technology } \\
\text { at } 1,000 \mathrm{BC}\end{array}$ & $0.41^{* * *}$ & $0.66 * * *$ & 1.00 & & & \\
\hline $\begin{array}{l}\text { Technology } \\
\text { at 1CE }\end{array}$ & $0.60 * * *$ & $0.55^{* * *}$ & $0.64^{* * *}$ & 1.00 & & \\
\hline $\begin{array}{l}\text { Technology } \\
\text { at } 1,500 \mathrm{CE}\end{array}$ & $0.61^{* * *}$ & $0.69^{* * *}$ & $0.49^{* * *}$ & $0.59^{* * *}$ & 1.00 & \\
\hline $\begin{array}{l}\text { Genetic } \\
\text { distance }\end{array}$ & $-0.55^{* * *}$ & $-0.67 * * *$ & $-0.53 * * *$ & $-0.59 * * *$ & $-0.74^{* * *}$ & 1.00 \\
\hline
\end{tabular}

Note: $* * *$ indicates significance at the 1-percent level.

Table D.2: Explanatory Power of Each Principal Component of Historical Variables

\begin{tabular}{|l|l|l|}
\hline PC & Percentage explained & Cumulative \\
\hline 1 & 0.67 & 0.67 \\
\hline 2 & 0.11 & 0.78 \\
\hline 3 & 0.08 & 0.86 \\
\hline 4 & 0.07 & 0.93 \\
\hline 5 & 0.04 & 0.97 \\
\hline 6 & 0.03 & 1.00 \\
\hline
\end{tabular}

Table D.3: Correlation Coefficients of Proximate Factors

\begin{tabular}{|l|l|l|l|l|}
\hline & Political volatility & $\begin{array}{l}\text { Discretionary } \\
\text { fiscal policy }\end{array}$ & $\begin{array}{l}\text { Financial } \\
\text { development }\end{array}$ & FDI inflow \\
\hline Political volatility & 1.00 & & & \\
\hline $\begin{array}{l}\text { Discretionary } \\
\text { fiscal policy }\end{array}$ & $-0.37^{* * *}$ & 1.00 & & \\
\hline $\begin{array}{l}\text { Financial } \\
\text { development }\end{array}$ & $0.46^{* * *}$ & $-0.51^{* * *}$ & 1.00 & 1.00 \\
\hline FDI inflow & 0.18 & -0.12 & 0.14 & \\
\hline
\end{tabular}

Note: *** indicates significance at the 1-percent level.

Table D.4: Explanatory Power of Each Principal Component of Proximate Factors

\begin{tabular}{|l|l|l|}
\hline PC & Percentage explained & Cumulative \\
\hline 1 & 0.49 & 0.49 \\
\hline 2 & 0.24 & 0.73 \\
\hline 3 & 0.16 & 0.88 \\
\hline 4 & 0.12 & 1.00 \\
\hline
\end{tabular}




\section{Appendix E: A List of Countries}

Country Name

\begin{tabular}{|c|c|c|c|}
\hline Afghanistan & Czech Republic & Kyrgyz Republic & Russian Federation \\
\hline Albania & Denmark & Lao PDR & Rwanda \\
\hline Algeria & Dominican Republic & Latvia & Senegal \\
\hline Angola & Ecuador & Lesotho & Serbia \\
\hline Argentina & Egypt, Arab Rep. & Liberia & Sierra Leone \\
\hline Armenia & El Salvador & Libya & Singapore \\
\hline Australia & Estonia & Lithuania & Slovak Republic \\
\hline Austria & Ethiopia & Macedonia, FYR & Slovenia \\
\hline Azerbaijan & Fiji & Madagascar & South Africa \\
\hline Bangladesh & Finland & Malawi & Spain \\
\hline Belarus & France & Malaysia & Sri Lanka \\
\hline Belgium & Gabon & Mali & Sudan \\
\hline Benin & Gambia, The & Mauritania & Swaziland \\
\hline Bolivia & Georgia & Mauritius & Sweden \\
\hline Bosnia \& Herzegovina & Germany & Mexico & Switzerland \\
\hline Botswana & Ghana & Moldova & Syrian Arab Republic \\
\hline Brazil & Greece & Mongolia & Tajikistan \\
\hline Bulgaria & Guatemala & Morocco & Thailand \\
\hline Burkina Faso & Guinea & Mozambique & Togo \\
\hline Burundi & Guyana & Myanmar & Trinidad and Tobago \\
\hline Cambodia & Haiti & Nepal & Tunisia \\
\hline Cameroon & Honduras & Netherlands & Turkey \\
\hline Canada & Hong Kong & New Zealand & Turkmenistan \\
\hline Cape Verde & Hungary & Nicaragua & Uganda \\
\hline Central African Rep. & India & Niger & Ukraine \\
\hline Chad & Indonesia & Nigeria & United Kingdom \\
\hline Chile & Iran, Islamic Rep. & Norway & United States \\
\hline China & Ireland & Pakistan & Uruguay \\
\hline Colombia & Israel & Panama & Uzbekistan \\
\hline Congo, Dem. Rep. & Italy & Papua New Guinea & Venezuela, RB \\
\hline Congo, Rep. & Jamaica & Paraguay & Vietnam \\
\hline Costa Rica & Japan & Peru & Yemen, Rep. \\
\hline Cote d'Ivoire & Jordan & Philippines & Zambia \\
\hline Croatia & Kazakhstan & Poland & Zimbabwe \\
\hline Cuba & Kenya & Portugal & \\
\hline Cyprus & Korea, Rep. & Romania & \\
\hline
\end{tabular}


Editor, UWA Economics Discussion Papers:

Ernst Juerg Weber

Business School - Economics

University of Western Australia

35 Sterling Hwy

Crawley WA 6009

Australia

Email: ecoadmin@biz.uwa.edu.au

The Economics Discussion Papers are available at:

1980 - 2002: http://ecompapers.biz.uwa.edu.au/paper/PDF\%20of\%20Discussion\%20Papers/

Since 2001: http://ideas.repec.org/s/uwa/wpaper1.html

Since 2004: $\quad$ http://www.business.uwa.edu.au/school/disciplines/economics

\section{ECONOMICS DISCUSSION PAPERS}

2012

\begin{tabular}{|c|c|c|}
\hline $\begin{array}{l}\text { DP } \\
\text { NUMBER }\end{array}$ & AUTHORS & TITLE \\
\hline 12.01 & $\begin{array}{l}\text { Clements, K.W., Gao, G., and } \\
\text { Simpson, T. }\end{array}$ & $\begin{array}{l}\text { DISPARITIES IN INCOMES AND PRICES } \\
\text { INTERNATIONALLY }\end{array}$ \\
\hline 12.02 & Tyers, R. & $\begin{array}{l}\text { THE RISE AND ROBUSTNESS OF ECONOMIC FREEDOM } \\
\text { IN CHINA }\end{array}$ \\
\hline 12.03 & Golley, J. and Tyers, R. & $\begin{array}{l}\text { DEMOGRAPHIC DIVIDENDS, DEPENDENCIES AND } \\
\text { ECONOMIC GROWTH IN CHINA AND INDIA }\end{array}$ \\
\hline 12.04 & Tyers, R. & LOOKING INWARD FOR GROWTH \\
\hline 12.05 & Knight, K. and McLure, M. & THE ELUSIVE ARTHUR PIGOU \\
\hline 12.06 & McLure, M. & $\begin{array}{l}\text { ONE HUNDRED YEARS FROM TODAY: A. C. PIGOU'S } \\
\text { WEALTH AND WELFARE }\end{array}$ \\
\hline 12.07 & Khuu, A. and Weber, E.J. & HOW AUSTRALIAN FARMERS DEAL WITH RISK \\
\hline 12.08 & Chen, M. and Clements, K.W. & PATTERNS IN WORLD METALS PRICES \\
\hline 12.09 & Clements, K.W. & UWA ECONOMICS HONOURS \\
\hline 12.10 & Golley, J. and Tyers, R. & $\begin{array}{l}\text { CHINA'S GENDER IMBALANCE AND ITS ECONOMIC } \\
\text { PERFORMANCE }\end{array}$ \\
\hline 12.11 & Weber, E.J. & $\begin{array}{l}\text { AUSTRALIAN FISCAL POLICY IN THE AFTERMATH OF } \\
\text { THE GLOBAL FINANCIAL CRISIS }\end{array}$ \\
\hline 12.12 & Hartley, P.R. and Medlock III, K.B. & $\begin{array}{l}\text { CHANGES IN THE OPERATIONAL EFFICIENCY OF } \\
\text { NATIONAL OIL COMPANIES }\end{array}$ \\
\hline 12.13 & Li, L. & $\begin{array}{l}\text { HOW MUCH ARE RESOURCE PROJECTS WORTH? A } \\
\text { CAPITAL MARKET PERSPECTIVE }\end{array}$ \\
\hline 12.14 & Chen, A. and Groenewold, N. & $\begin{array}{l}\text { THE REGIONAL ECONOMIC EFFECTS OF A } \\
\text { REDUCTION IN CARBON EMISSIONS AND AN } \\
\text { EVALUATION OF OFFSETTING POLICIES IN CHINA }\end{array}$ \\
\hline 12.15 & Collins, J., Baer, B. and Weber, E.J. & $\begin{array}{l}\text { SEXUAL SELECTION, CONSPICUOUS CONSUMPTION } \\
\text { AND ECONOMIC GROWTH }\end{array}$ \\
\hline
\end{tabular}




\begin{tabular}{|c|c|c|}
\hline \multicolumn{3}{|c|}{$\begin{array}{l}\text { ECONOMICS DISCUSSION PAPERS } \\
2012\end{array}$} \\
\hline $\begin{array}{l}\text { DP } \\
\text { NUMBER }\end{array}$ & AUTHORS & TITLE \\
\hline 12.16 & $\mathrm{Wu}, \mathrm{Y}$. & TRENDS AND PROSPECTS IN CHINA'S R\&D SECTOR \\
\hline 12.17 & Cheong, T.S. and Wu, Y. & $\begin{array}{l}\text { INTRA-PROVINCIAL INEQUALITY IN CHINA: AN } \\
\text { ANALYSIS OF COUNTY-LEVEL DATA }\end{array}$ \\
\hline 12.18 & Cheong, T.S. & THE PATTERNS OF REGIONAL INEQUALITY IN CHINA \\
\hline 12.19 & $\mathrm{Wu}, \mathrm{Y}$. & $\begin{array}{l}\text { ELECTRICITY MARKET INTEGRATION: GLOBAL } \\
\text { TRENDS AND IMPLICATIONS FOR THE EAS REGION }\end{array}$ \\
\hline 12.20 & Knight, K. & $\begin{array}{l}\text { EXEGESIS OF DIGITAL TEXT FROM THE HISTORY OF } \\
\text { ECONOMIC THOUGHT: A COMPARATIVE } \\
\text { EXPLORATORY TEST }\end{array}$ \\
\hline 12.21 & Chatterjee, I. & $\begin{array}{l}\text { COSTLY REPORTING, EX-POST MONITORING, AND } \\
\text { COMMERCIAL PIRACY: A GAME THEORETIC } \\
\text { ANALYSIS }\end{array}$ \\
\hline 12.22 & Pen, S.E. & QUALITY-CONSTANT ILLICIT DRUG PRICES \\
\hline 12.23 & Cheong, T.S. and $\mathrm{Wu}, \mathrm{Y}$. & $\begin{array}{l}\text { REGIONAL DISPARITY, TRANSITIONAL DYNAMICS } \\
\text { AND CONVERGENCE IN CHINA }\end{array}$ \\
\hline 12.24 & Ezzati, P. & $\begin{array}{l}\text { FINANCIAL MARKETS INTEGRATION OF IRAN } \\
\text { WITHIN THE MIDDLE EAST AND WITH THE REST OF } \\
\text { THE WORLD }\end{array}$ \\
\hline 12.25 & Kwan, F., Wu, Y. and Zhuo, S. & $\begin{array}{l}\text { RE-EXAMINATION OF THE SURPLUS AGRICULTURAL } \\
\text { LABOUR IN CHINA }\end{array}$ \\
\hline 12.26 & Wu, Y. & R\&D BEHAVIOUR IN CHINESE FIRMS \\
\hline 12.27 & Tang, S.H.K. and Yung, L.C.W. & $\begin{array}{l}\text { MAIDS OR MENTORS? THE EFFECTS OF LIVE-IN } \\
\text { FOREIGN DOMESTIC WORKERS ON SCHOOL } \\
\text { CHILDREN'S EDUCATIONAL ACHIEVEMENT IN HONG } \\
\text { KONG }\end{array}$ \\
\hline 12.28 & Groenewold, N. & $\begin{array}{l}\text { AUSTRALIA AND THE GFC: SAVED BY ASTUTE } \\
\text { FISCAL POLICY? }\end{array}$ \\
\hline
\end{tabular}




\section{ECONOMICS DISCUSSION PAPERS}

2013

\begin{tabular}{|c|c|c|}
\hline $\begin{array}{l}\text { DP } \\
\text { NUMBER }\end{array}$ & AUTHORS & TITLE \\
\hline 13.01 & $\begin{array}{l}\text { Chen, M., Clements, K.W. and } \\
\text { Gao, G. }\end{array}$ & THREE FACTS ABOUT WORLD METAL PRICES \\
\hline 13.02 & Collins, J. and Richards, O. & $\begin{array}{l}\text { EVOLUTION, FERTILITY AND THE AGEING } \\
\text { POPULATION }\end{array}$ \\
\hline 13.03 & $\begin{array}{l}\text { Clements, K., Genberg, H., } \\
\text { Harberger, A., Lothian, J., } \\
\text { Mundell, R., Sonnenschein, H. and } \\
\text { Tolley, G. }\end{array}$ & LARRY SJAASTAD, 1934-2012 \\
\hline 13.04 & Robitaille, M.C. and Chatterjee, I. & MOTHERS-IN-LAW AND SON PREFERENCE IN INDIA \\
\hline 13.05 & Clements, K.W. and Izan, I.H.Y. & $\begin{array}{l}\text { REPORT ON THE } 25^{\mathrm{TH}} \text { PHD CONFERENCE IN } \\
\text { ECONOMICS AND BUSINESS }\end{array}$ \\
\hline 13.06 & Walker, A. and Tyers, R. & QUANTIFYING AUSTRALIA’S “THREE SPEED” BOOM \\
\hline 13.07 & $\mathrm{Yu}, \mathrm{F}$. and $\mathrm{Wu}, \mathrm{Y}$. & PATENT EXAMINATION AND DISGUISED PROTECTION \\
\hline 13.08 & $\mathrm{Yu}, \mathrm{F}$. and $\mathrm{Wu}, \mathrm{Y}$. & $\begin{array}{l}\text { PATENT CITATIONS AND KNOWLEDGE SPILLOVERS: } \\
\text { AN ANALYSIS OF CHINESE PATENTS REGISTER IN } \\
\text { THE US }\end{array}$ \\
\hline 13.09 & Chatterjee, I. and Saha, B. & BARGAINING DELEGATION IN MONOPOLY \\
\hline 13.10 & Cheong, T.S. and Wu, Y. & $\begin{array}{l}\text { GLOBALIZATION AND REGIONAL INEQUALITY IN } \\
\text { CHINA }\end{array}$ \\
\hline 13.11 & Cheong, T.S. and Wu, Y. & INEQUALITY AND CRIME RATES IN CHINA \\
\hline 13.12 & Robertson, P.E. and Ye, L. & ON THE EXISTENCE OF A MIDDLE INCOME TRAP \\
\hline 13.13 & Robertson, P.E. & THE GLOBAL IMPACT OF CHINA’S GROWTH \\
\hline 13.14 & $\begin{array}{l}\text { Hanaki, N., Jacquemet, N., } \\
\text { Luchini, S., and Zylbersztejn, A. }\end{array}$ & $\begin{array}{l}\text { BOUNDED RATIONALITY AND STRATEGIC } \\
\text { UNCERTAINTY IN A SIMPLE DOMINANCE SOLVABLE } \\
\text { GAME }\end{array}$ \\
\hline 13.15 & $\begin{array}{l}\text { Okatch, Z., Siddique, A. and } \\
\text { Rammohan, A. }\end{array}$ & $\begin{array}{l}\text { DETERMINANTS OF INCOME INEQUALITY IN } \\
\text { BOTSWANA }\end{array}$ \\
\hline 13.16 & Clements, K.W. and Gao, G. & $\begin{array}{l}\text { A MULTI-MARKET APPROACH TO MEASURING THE } \\
\text { CYCLE }\end{array}$ \\
\hline 13.17 & Chatterjee, I. and Ray, R. & $\begin{array}{l}\text { THE ROLE OF INSTITUTIONS IN THE INCIDENCE OF } \\
\text { CRIME AND CORRUPTION }\end{array}$ \\
\hline 13.18 & Fu, D. and Wu, Y. & $\begin{array}{l}\text { EXPORT SURVIVAL PATTERN AND DETERMINANTS } \\
\text { OF CHINESE MANUFACTURING FIRMS }\end{array}$ \\
\hline 13.19 & Shi, X., Wu, Y. and Zhao, D. & $\begin{array}{l}\text { KNOWLEDGE INTENSIVE BUSINESS SERVICES AND } \\
\text { THEIR IMPACT ON INNOVATION IN CHINA }\end{array}$ \\
\hline 13.20 & $\begin{array}{l}\text { Tyers, R., Zhang, Y. and } \\
\text { Cheong, T.S. }\end{array}$ & $\begin{array}{l}\text { CHINA'S SAVING AND GLOBAL ECONOMIC } \\
\text { PERFORMANCE }\end{array}$ \\
\hline 13.21 & Collins, J., Baer, B. and Weber, E.J. & $\begin{array}{l}\text { POPULATION, TECHNOLOGICAL PROGRESS AND THE } \\
\text { EVOLUTION OF INNOVATIVE POTENTIAL }\end{array}$ \\
\hline 13.22 & Hartley, P.R. & THE FUTURE OF LONG-TERM LNG CONTRACTS \\
\hline 13.23 & Tyers, R. & $\begin{array}{l}\text { A SIMPLE MODEL TO STUDY GLOBAL } \\
\text { MACROECONOMIC INTERDEPENDENCE }\end{array}$ \\
\hline
\end{tabular}




\begin{tabular}{|c|c|c|}
\hline \multicolumn{3}{|c|}{$\begin{array}{l}\text { ECONOMICS DISCUSSION PAPERS } \\
2013\end{array}$} \\
\hline $\begin{array}{l}\text { DP } \\
\text { NUMBER }\end{array}$ & AUTHORS & TITLE \\
\hline 13.24 & McLure, M. & $\begin{array}{l}\text { REFLECTIONS ON THE QUANTITY THEORY: PIGOU IN } \\
1917 \text { AND PARETO IN 1920-21 }\end{array}$ \\
\hline 13.25 & Chen, A. and Groenewold, N. & $\begin{array}{l}\text { REGIONAL EFFECTS OF AN EMISSIONS-REDUCTION } \\
\text { POLICY IN CHINA: THE IMPORTANCE OF THE } \\
\text { GOVERNMENT FINANCING METHOD }\end{array}$ \\
\hline 13.26 & Siddique, M.A.B. & $\begin{array}{l}\text { TRADE RELATIONS BETWEEN AUSTRALIA AND } \\
\text { THAILAND: } 1990 \text { TO } 2011\end{array}$ \\
\hline 13.27 & Li, B. and Zhang, J. & $\begin{array}{l}\text { GOVERNMENT DEBT IN AN INTERGENERATIONAL } \\
\text { MODEL OF ECONOMIC GROWTH, ENDOGENOUS } \\
\text { FERTILITY, AND ELASTIC LABOR WITH AN } \\
\text { APPLICATION TO JAPAN }\end{array}$ \\
\hline 13.28 & Robitaille, M. and Chatterjee, I. & $\begin{array}{l}\text { SEX-SELECTIVE ABORTIONS AND INFANT } \\
\text { MORTALITY IN INDIA: THE ROLE OF PARENTS’ } \\
\text { STATED SON PREFERENCE }\end{array}$ \\
\hline 13.29 & Ezzati, P. & $\begin{array}{l}\text { ANALYSIS OF VOLATILITY SPILLOVER EFFECTS: } \\
\text { TWO-STAGE PROCEDURE BASED ON A MODIFIED } \\
\text { GARCH-M }\end{array}$ \\
\hline 13.30 & Robertson, P. E. & $\begin{array}{l}\text { DOES A FREE MARKET ECONOMY MAKE AUSTRALIA } \\
\text { MORE OR LESS SECURE IN A GLOBALISED WORLD? }\end{array}$ \\
\hline 13.31 & $\begin{array}{l}\text { Das, S., Ghate, C. and } \\
\text { Robertson, P. E. }\end{array}$ & $\begin{array}{l}\text { REMOTENESS AND UNBALANCED GROWTH: } \\
\text { UNDERSTANDING DIVERGENCE ACROSS INDIAN } \\
\text { DISTRICTS }\end{array}$ \\
\hline 13.32 & Robertson, P.E. and Sin, A. & $\begin{array}{l}\text { MEASURING HARD POWER: CHINA’S ECONOMIC } \\
\text { GROWTH AND MILITARY CAPACITY }\end{array}$ \\
\hline 13.33 & Wu, Y. & $\begin{array}{l}\text { TRENDS AND PROSPECTS FOR THE RENEWABLE } \\
\text { ENERGY SECTOR IN THE EAS REGION }\end{array}$ \\
\hline 13.34 & $\begin{array}{l}\text { Yang, S., Zhao, D., Wu, Y. and } \\
\text { Fan, J. }\end{array}$ & $\begin{array}{l}\text { REGIONAL VARIATION IN CARBON EMISSION AND } \\
\text { ITS DRIVING FORCES IN CHINA: AN INDEX } \\
\text { DECOMPOSITION ANALYSIS }\end{array}$ \\
\hline
\end{tabular}




\begin{tabular}{|c|c|c|}
\hline \multicolumn{3}{|c|}{$\begin{array}{l}\text { ECONOMICS DISCUSSION PAPERS } \\
2014\end{array}$} \\
\hline $\begin{array}{l}\text { DP } \\
\text { NUMBER }\end{array}$ & AUTHORS & TITLE \\
\hline 14.01 & $\begin{array}{l}\text { Boediono, Vice President of the Republic } \\
\text { of Indonesia }\end{array}$ & $\begin{array}{l}\text { THE CHALLENGES OF POLICY MAKING IN A } \\
\text { YOUNG DEMOCRACY: THE CASE OF INDONESIA } \\
\text { (52ND SHANN MEMORIAL LECTURE, 2013) }\end{array}$ \\
\hline 14.02 & Metaxas, P.E. and Weber, E.J. & $\begin{array}{l}\text { AN AUSTRALIAN CONTRIBUTION TO } \\
\text { INTERNATIONAL TRADE THEORY: THE } \\
\text { DEPENDENT ECONOMY MODEL }\end{array}$ \\
\hline 14.03 & Fan, J., Zhao, D., Wu, Y. and Wei, J. & $\begin{array}{l}\text { CARBON PRICING AND ELECTRICITY MARKET } \\
\text { REFORMS IN CHINA }\end{array}$ \\
\hline 14.04 & McLure, M. & $\begin{array}{l}\text { A.C. PIGOU’S MEMBERSHIP OF THE } \\
\text { ‘CHAMBERLAIN-BRADBURY’ COMMITTEE. } \\
\text { PART I: THE HISTORICAL CONTEXT }\end{array}$ \\
\hline 14.05 & McLure, M. & $\begin{array}{l}\text { A.C. PIGOU’S MEMBERSHIP OF THE } \\
\text { 'CHAMBERLAIN-BRADBURY’ COMMITTEE. } \\
\text { PART II: ‘TRANSITIONAL’ AND ‘ONGOING’ ISSUES }\end{array}$ \\
\hline 14.06 & King, J.E. and McLure, M. & HISTORY OF THE CONCEPT OF VALUE \\
\hline 14.07 & Williams, A. & $\begin{array}{l}\text { A GLOBAL INDEX OF INFORMATION AND } \\
\text { POLITICAL TRANSPARENCY }\end{array}$ \\
\hline 14.08 & Knight, K. & $\begin{array}{l}\text { A.C. PIGOU'S THE THEORY OF UNEMPLOYMENT } \\
\text { AND ITS CORRIGENDA: THE LETTERS OF } \\
\text { MAURICE ALLEN, ARTHUR L. BOWLEY, RICHARD } \\
\text { KAHN AND DENNIS ROBERTSON }\end{array}$ \\
\hline 14.09 & Cheong, T.S. and Wu, Y. & $\begin{array}{l}\text { THE IMPACTS OF STRUCTURAL RANSFORMATION } \\
\text { AND INDUSTRIAL UPGRADING ON REGIONAL } \\
\text { INEQUALITY IN CHINA }\end{array}$ \\
\hline 14.10 & $\begin{array}{l}\text { Chowdhury, M.H., Dewan, M.N.A., } \\
\text { Quaddus, M., Naude, M. and } \\
\text { Siddique, A. }\end{array}$ & $\begin{array}{l}\text { GENDER EQUALITY AND SUSTAINABLE } \\
\text { DEVELOPMENT WITH A FOCUS ON THE COASTAL } \\
\text { FISHING COMMUNITY OF BANGLADESH }\end{array}$ \\
\hline 14.11 & Bon, J. & $\begin{array}{l}\text { UWA DISCUSSION PAPERS IN ECONOMICS: THE } \\
\text { FIRST } 750\end{array}$ \\
\hline 14.12 & Finlay, K. and Magnusson, L.M. & $\begin{array}{l}\text { BOOTSTRAP METHODS FOR INFERENCE WITH } \\
\text { CLUSTER-SAMPLE IV MODELS }\end{array}$ \\
\hline 14.13 & Chen, A. and Groenewold, N. & $\begin{array}{l}\text { THE EFFECTS OF MACROECONOMIC SHOCKS ON } \\
\text { THE DISTRIBUTION OF PROVINCIAL OUTPUT IN } \\
\text { CHINA: ESTIMATES FROM A RESTRICTED VAR } \\
\text { MODEL }\end{array}$ \\
\hline 14.14 & Hartley, P.R. and Medlock III, K.B. & $\begin{array}{l}\text { THE VALLEY OF DEATH FOR NEW ENERGY } \\
\text { TECHNOLOGIES }\end{array}$ \\
\hline 14.15 & $\begin{array}{l}\text { Hartley, P.R., Medlock III, K.B., } \\
\text { Temzelides, T. and Zhang, X. }\end{array}$ & $\begin{array}{l}\text { LOCAL EMPLOYMENT IMPACT FROM COMPETING } \\
\text { ENERGY SOURCES: SHALE GAS VERSUS WIND } \\
\text { GENERATION IN TEXAS }\end{array}$ \\
\hline 14.16 & Tyers, R. and Zhang, Y. & $\begin{array}{l}\text { SHORT RUN EFFECTS OF THE ECONOMIC REFORM } \\
\text { AGENDA }\end{array}$ \\
\hline 14.17 & Clements, K.W., Si, J. and Simpson, T. & UNDERSTANDING NEW RESOURCE PROJECTS \\
\hline 14.18 & Tyers, R. & $\begin{array}{l}\text { SERVICE OLIGOPOLIES AND AUSTRALIA’S } \\
\text { ECONOMY-WIDE PERFORMANCE }\end{array}$ \\
\hline 14.19 & Tyers, R. and Zhang, Y. & $\begin{array}{l}\text { REAL EXCHANGE RATE DETERMINATION AND } \\
\text { THE CHINA PUZZLE }\end{array}$ \\
\hline
\end{tabular}




\begin{tabular}{|c|c|c|}
\hline \multicolumn{3}{|c|}{$\begin{array}{l}\text { ECONOMICS DISCUSSION PAPERS } \\
2014\end{array}$} \\
\hline $\begin{array}{l}\text { DP } \\
\text { NUMBER }\end{array}$ & AUTHORS & TITLE \\
\hline 14.20 & Ingram, S.R. & $\begin{array}{l}\text { COMMODITY PRICE CHANGES ARE } \\
\text { CONCENTRATED AT THE END OF THE CYCLE }\end{array}$ \\
\hline 14.21 & Cheong, T.S. and Wu, Y. & $\begin{array}{l}\text { CHINA'S INDUSTRIAL OUTPUT: A COUNTY-LEVEL } \\
\text { STUDY USING A NEW FRAMEWORK OF } \\
\text { DISTRIBUTION DYNAMICS ANALYSIS }\end{array}$ \\
\hline 14.22 & $\begin{array}{l}\text { Siddique, M.A.B., Wibowo, H. and } \\
\text { Wu, Y. }\end{array}$ & $\begin{array}{l}\text { FISCAL DECENTRALISATION AND INEQUALITY IN } \\
\text { INDONESIA: 1999-2008 }\end{array}$ \\
\hline 14.23 & Tyers, R. & $\begin{array}{l}\text { ASYMMETRY IN BOOM-BUST SHOCKS: } \\
\text { AUSTRALIAN PERFORMANCE WITH OLIGOPOLY }\end{array}$ \\
\hline 14.24 & Arora, V., Tyers, R. and Zhang, Y. & $\begin{array}{l}\text { RECONSTRUCTING THE SAVINGS GLUT: THE } \\
\text { GLOBAL IMPLICATIONS OF ASIAN EXCESS } \\
\text { SAVING }\end{array}$ \\
\hline 14.25 & Tyers, R. & $\begin{array}{l}\text { INTERNATIONAL EFFECTS OF CHINA’S RISE AND } \\
\text { TRANSITION: NEOCLASSICAL AND KEYNESIAN } \\
\text { PERSPECTIVES }\end{array}$ \\
\hline 14.26 & Milton, S. and Siddique, M.A.B. & $\begin{array}{l}\text { TRADE CREATION AND DIVERSION UNDER THE } \\
\text { THAILAND-AUSTRALIA FREE TRADE } \\
\text { AGREEMENT (TAFTA) }\end{array}$ \\
\hline 14.27 & Clements, K.W. and Li, L. & VALUING RESOURCE INVESTMENTS \\
\hline 14.28 & Tyers, R. & $\begin{array}{l}\text { PESSIMISM SHOCKS IN A MODEL OF GLOBAL } \\
\text { MACROECONOMIC INTERDEPENDENCE }\end{array}$ \\
\hline 14.29 & Iqbal, K. and Siddique, M.A.B. & $\begin{array}{l}\text { THE IMPACT OF CLIMATE CHANGE ON } \\
\text { AGRICULTURAL PRODUCTIVITY: EVIDENCE } \\
\text { FROM PANEL DATA OF BANGLADESH }\end{array}$ \\
\hline 14.30 & Ezzati, P. & $\begin{array}{l}\text { MONETARY POLICY RESPONSES TO FOREIGN } \\
\text { FINANCIAL MARKET SHOCKS: APPLICATION OF A } \\
\text { MODIFIED OPEN-ECONOMY TAYLOR RULE }\end{array}$ \\
\hline 14.31 & Tang, S.H.K. and Leung, C.K.Y. & $\begin{array}{l}\text { THE DEEP HISTORICAL ROOTS OF } \\
\text { MACROECONOMIC VOLATILITY }\end{array}$ \\
\hline 14.32 & Arthmar, R. and McLure, M. & $\begin{array}{l}\text { PIGOU, DEL VECCHIO AND SRAFFA: THE } 1955 \\
\text { INTERNATIONAL ‘ANTONIO FELTRINELLI’ PRIZE } \\
\text { FOR THE ECONOMIC AND SOCIAL SCIENCES }\end{array}$ \\
\hline 14.33 & McLure, M. & $\begin{array}{l}\text { A-HISTORIAL ECONOMIC DYNAMICS: A BOOK } \\
\text { REVIEW }\end{array}$ \\
\hline 14.34 & Clements, K.W. and Gao, G. & $\begin{array}{l}\text { THE ROTTERDAM DEMAND MODEL HALF A } \\
\text { CENTURY ON }\end{array}$ \\
\hline
\end{tabular}

